\title{
La experiencia de las imágenes marianas a finales de la Edad Media: el Miroir Historial de Vicente de Beauvais*
}

\section{The experience of Marian images at the end of the Middle Ages: the Miroir Historial of Vincent of Beauvais}

\author{
Fuensanta Murcia Nicolás \\ Centre d'Études Supérieures de Civilisation Médiévale, Université de Poitiers - CNRS
}

Fecha de recepción: 27 de febrero de 2020

Fecha de aceptación: 17 de julio de 2020
Anuario del Departamento de Historia y Teoría del Arte

vol. 32, 2020, pp. 11-28

ISSN: 1130-5517, eISSN: 2530-3562

https://doi.org/10.15366/anuario2020.32.001

\section{RESUMEN}

Las imágenes de culto adquieren un gran protagonismo a finales de la Edad Media gracias a la legitimación de su carácter sagrado y milagroso. Un caso extremadamente interesante son las efigies marianas, que no solo se ven favorecidas por estas circunstancias sino también por la experiencia devocional que suscita su modelo, la Virgen. El presente artículo pretende explorar la representación de estas imágenes en los manuscritos del Miroir Historial, la traducción del Speculum Historiale realizada en el siglo XIV por Jean de Vignay. En sus miniaturas vemos cómo estas van perdiendo su condición de objeto para pasar a ser figuras "casi vivientes", situadas a un mismo nivel de realidad que el protagonista, una presentación ligada a los rasgos del personaje que representan y la búsqueda de una religiosidad más próxima. Así pues, la Virgen, mediadora cercana por excelencia, deja de ser representada a estar presente en su imagen, la cual ya no es una simple escultura o pintura, sino más bien su sustituta eficiente y real.

\section{PALABRAS CLAVE}

Estudios visuales. Imágenes marianas. Imágenes milagrosas. Manuscritos iluminados. Milagros de la Virgen. Miroir Historial.

\begin{abstract}
The cult images acquired a great prominence at the end of the Middle Ages thanks to the legitimisation of their sacred and miraculous character. An extremely interesting case is the Marian effigies, which are not only favoured by these circumstances but also by the devotional experience that their model, the Virgin, arouses. This article aims to explore the representation of these images in the manuscripts of the Miroir Historial, the translation of the Speculum Historiale made in the $14^{\text {th }}$ century by Jean de Vignay. In their miniatures we see how they are losing their object status to become "almost living" figures, located at the same level of reality as the protagonist, a presentation linked to the character traits they represent and the search for an intimate religious experience. Thus, the Virgin, a near mediator par excellence, ceases to be represented to be present in her image, which is no longer a simple sculpture or painting, but rather as her efficient and real substitute.
\end{abstract}

\section{KEY WORDS}

Visual studies. Marian images. Miraculous images. Illuminated manuscripts. Miracles of the Virgin. Miroir Historial.

\footnotetext{
* Esta investigación ha sido posible gracias al Programa de Formación Postdoctoral de la Fundación Séneca de la Región de Murcia y forma parte del proyecto de investigación PGC2018-098550-B-100 "La Experiencia de las Imágenes (3)" del Ministerio de Ciencia, Innovación y Universidades. También quisiera agradecer las sugerencias y aportaciones de los evaluadores, que han enriquecido el resultado final de este artículo.
} 
La Virgen como ideal de espiritualidad subjetiva, está al mismo tiempo materializada y representada en sus representaciones y, al romper esa relación estricta entre la imagen y el prototipo, ella es la que más se mueve y es, por tanto, literalmente la más mediadora de las imágenes góticas ${ }^{1}$.

Tal y como afirma Michael Camille, la particularidad de las imágenes de la Virgen en los últimos siglos de Edad Media va a residir en cómo estas rompen la relación estricta que existe entre el personaje sagrado y aquello que lo representa. La eclosión de una nueva cultura visual en torno a las imágenes cristianas, su estatus y sus usos pone de manifiesto la pronta repercusión que tuvieron las discusiones teóricas, no obstante existen tres factores que no solo influyen en el interés que podía despertar el culto a las imágenes, sino también en la forma de presentación y los recursos iconográficos que encontramos en el arte bajomedieval. El primero es la legitimación de la imagen como objeto sagrado ${ }^{2}$. Si bien el Occidente medieval parte de su propia tradición sobre dicho estatus, la asimilación de los preceptos bizantinos fue determinante para la construcción de la teoría occidental ${ }^{3}$. Esta legitimación, presente en el discurso teológico, impulsó la creación de nuevos códigos visuales que, a su vez, se ajustaban a una realidad social ${ }^{4}$. El segundo son los cambios en el concepto de materialidad cristiana. Las nuevas corrientes de pensamiento aristotélico ponen su atención en las relaciones entre lo natural y lo sobrenatural, y en cómo lo divino se manifiesta en el mundo terrenal ${ }^{5}$, una perspectiva que enfatizó aún más las propiedades taumatúrgicas y milagrosas de

1 Michael CAMILLE, El ídolo gótico. Ideología y creación de imágenes en el arte medieval, Madrid, Akal, 2000, p. 243.

2 Previamente al resurgimiento de la escultura monumental, la respuesta del mundo carolingio al II Concilio de Nicea (787) había desvestido a la imagen de su carácter sagrado, quedando relegada a una función didáctica. Olivier BoulNOIs, $A u$-delà de l'image. Une archéologie du visuel au Moyen Âge (Ve-XVe siècles), París, Seuil, 2008, pp. 82 y 92-93; Leslie BRUBAKER, "Introduction: The Sacred Image", en R. Ousterhout y L. Brubaker (eds.), The Sacred Image East and West, Chicago, University of Illinois, 1995, p. 14; Thomas F.X. Noble, Images, Iconoclasm and the Carolingians, Filadelfia, University of Pennsylvania Press, 2009, pp. 366-370. Sobre la postura carolingia acerca de las imágenes y su carácter sagrado, Marie-France AuZÉPY, "Francfort et Nicée II", en R. Berndt (ed.), Das Frankfurter Konzil von 794, Frankfurt, Selbstverlag der Gesellschaft for Mittelrheinische Kirchengeschichte, 1997, vol. 2, pp. 279-300; Alain BESANÇON, L'image interdite. Une historie intellectuelle de l'iconoclasme, París, Fayard, 1994, pp. 208-209; Alejandro GARCÍA AvILÉs, "Transitus: actitudes hacia la sacralidad de las imágenes en el Occidente Medieval”, en G. Boto (ed.), Imágenes de Culto, Murcia, Conserjería de Cultura de la Región de Murcia, 2010, pp. 25-26; Thomas F.X. NoBle, 2009, p. 187.

3 Las traducciones de la obra de Juan Damasceno a finales del siglo XII impulsaron la revalorización de los postulados bizantinos. Autores como Pedro Lombardo y Alano de Lille vuelven a reflexionar sobre la "manera griega" para distanciarse del paradigma de Gregorio Magno y admitir que la imagen es venerada, no adorada, para así honrar a su prototipo. Alejandro GARCíA AVILÉs, 2010, p. 33; Herbert Kessler, "Gregory the Great and the image theory in Northern Europe during the Twelfth and Thirteenth Centuries", en C. Rudolph (ed.), A Companion to Medieval Art: Romanesque and Gothic in Northern Europe, Oxford, Blackwell, 2006, p. 155; Jean-Claude Schmitт, "L'Occident, Nicée II et les images du VIII" au XIII" siècle", en F. Boespflug y N. Lossky (eds.), Nicée II, 787-1987. Douze siècles d'images religieuses, París, Cerf, 1987, pp. 291-299.

4 Para Michael Camille "las iconografías nuevas se adaptan a las nuevas instituciones, leyes y prohibiciones. No describen o reflejan meramente una nueva situación, sino que son producto de unos procesos sociales y, a menudo, instrumentos de acción social", una perspectiva que se complementa con la propuesta de la Antropología Histórica de las Imágenes, la cual permite crear un marco para el estudio de las imágenes materiales a través de su función cultural. Jérôme BASCHET, L'iconographie médiévale, París, Gallimard, 2008, pp. 25-64; Hans Belting, Pour une anthropologie des images, París, Gallimard, 2004, p. 14; Michael CAmille, 2000, p. 24; Jean-Claude Schmitt, Le corps des images, París, Gallimard, 2002, pp. 35-62.

5 El pensamiento escolástico y la postura de la Iglesia a raíz del IV Concilio de Letrán (1215) añaden una nueva dimensión visual a la experiencia religiosa. El impulso del "ver para creer" pone la atención en los fenómenos milagrosos, ya que son considerados una muestra del poder de Dios en el mundo de los hombres. Caroline Bynum, Christian Materiality. An essay on religion in Late Middle Europe, Nueva York, Zone Books, 2011, p. 140; Alejandro GARCíA AvILÉs, "Imágenes vivientes: idolatría y herejía en las 'Cantigas' de Alfonso X”, Goya, 321 (2007), p. 234; Idem, 2010, p. 533; Deirdre E. JACKson, Marvellous to behold. Miracles in Medieval Manuscripts, Londres, British Library, 2007, p. 6; Steven Justice, "Did the Middle Ages believe in their miracles?", Representations, vol. 4, 1 (2008), pp. 1-29; Miri RubIn, Corpus Christi. The Eucharist in Late Medieval Culture, Cambridge, Cambridge University Press, 1991, p. 112. 
las imágenes ${ }^{6}$. Y el tercero es la relación con la naturaleza y culto del modelo, cómo influyen los rasgos del personaje sagrado en la experiencia religiosa de sus representaciones ${ }^{7}$.

En este caso, el culto a la Virgen experimenta una importante transformación a partir del siglo XII, cuando toda la teología mariana se estructura en torno a su atributo de mediadora ${ }^{8}$. No obstante, con anterioridad, los milagros se habían convertido en una prueba fehaciente y real de su poder mediador. Fulberto de Chartres (960-1028) en su sermón dedicado a la Natividad de María evoca varias de estas historias para implorar su intercesión:

Santa Madre de Dios, perpetua Virgen María, ¿Quién ha sido engañando cuando ha confiado en tí? Absolutamente nadie. Mi señora, se misericordiosa y apacible, como lo fuiste con el vicario Teófilo, quien renegó de Cristo y que gracias a ti fue perdonado. Se misericordiosa y apacible, como lo fuiste con María Egipcíaca, quien te tomó como garante entre ella misma y Dios, y mereció ser salvada. Se misericordiosa y apacible, como lo fuiste con el pequeño niño judío, a quien salvaste del horno del fuego ardiente, como me liberaste a mí del fuego del deseo carnal por tu divina intervención y plegarias. Se conmigo, piadosa señora, y con nuestra villa misericordiosa y apacible, como lo fuiste con el obispo Basilio y la iglesia de Cesarea, liberándolos de Julián el Apóstata. Se misericordiosa y apacible, como lo fuiste con el obispo Bonifacio, liberándolo de su deuda 9 .

El vínculo entre lo sobrenatural y la mediación influye directamente en la experiencia de las imágenes marianas, ya que los fieles se aproximarán a ellas para demandar la intervención de la Virgen. Por este

\footnotetext{
${ }^{6}$ El milagro es uno de los factores más determinantes en el proceso de legitimación de las imágenes cristianas. Aunque el siglo XIII supone un punto de inflexión importante por el desarrollo de nuevos marcos teóricos, el Occidente medieval poseía una larga tradición literaria que atestiguaba la existencia y culto de imágenes milagrosas. Esta relación ha sido brillantemente explorada por JeanMarie Sansterre, de cuya amplia trayectoria resaltamos "Attitudes occidentales à l'égard des miracles d'images dans le Haut Moyen Âge”, Annales. Histoire, Sciences Sociales, 6 (1998), pp. 1219-1241; Idem, "L'image blessée, l'image souffrante : quelques récits de miracles entre Orient et Occident (VI'-XII ${ }^{\mathrm{e}}$ siècles)", en J. M. Sansterre y J.C. Schmitt (eds.), Les images dans les sociétés médiévales : pour une historie comparée, Roma-Bruselas, Bulletin de l'Institute Historique Belge de Rome, 1999, pp. 113-130; Idem, "Visions et miracles en relation avec le crucifix dans les récits des $\mathrm{X}^{\mathrm{e}}-\mathrm{XI}^{\mathrm{e}}$ siècles", en M. Camillo Ferrari y A. Meyer (eds.), Il Volto Santo in Europa. Culto e immagini del Crocifisso nel Medioevo, Luca, Istituto Storico Lucchese, 2005, pp. 387-406; Idem, "Miracles et images. Les relations entre l'image et le prototype céleste d'après quelques récits des X ${ }^{\mathrm{e}}$-XIII ${ }^{\mathrm{e}}$ siècles", en A. Dierkens, G. Bartholeyns y T. Golsenne (eds.), Le Performance des Images, Bruselas, Éditions de l’Université de Bruxelles, 2010a, pp. 47-57; Idem, "La imagen activada por su prototipo celestial: milagros occidentales anteriores a mediados del siglo XIII", Codex Aquilarensis, 29 (2013), pp. 77-98.

7 A finales del siglo VIII, los llamados Tronos de Sabiduría surgen como objetos de altar con el fin de mostrar la autoridad espiritual de María y su papel en la Encarnación de Cristo. Aunque su culto no siempre estuvo ligado a la presencia de reliquias, su relación con lo milagroso estuvo muy influenciada por el poder de mediación de la Virgen. El énfasis en este cometido despertó aún más el interés por estas efigies, las cuales terminaron siendo el foco de plegarias y oraciones para provocar una intervención milagrosa. David Freedberg, El poder de las imágenes, Madrid, Cátedra, 2010, p. 119; Penny S. Gold, The Lady and the Virgin: image, attitude and experience in 12th century France, Chicago, Chicago University Press, 1985, pp. 43-49; Patrick HENRIET, "Invocatio Sanctificatorum Nominum. Efficacité de la prière et société chrétienne (IX ${ }^{\mathrm{e}}$-XII ${ }^{\mathrm{e}}$ siècle), en J.F. Cottier (ed.), La Prière en Latin de l'Antiquité au XVIe siècle, Turnhout, Brepols, 2006, p. 243; Jean-Marie SANSTERre y Patrick Henriet, "De 'l'inanimis imago' à 'l'omagen muy bella'. Méfiance à l'égard des images et essor de leur culte dans l'Espagne médiévale (VII'-XII siècles)”, Edad Media. Revista de Historia, 10 (2009), pp. 64-65.

${ }^{8}$ La construcción litúrgica y cultural en torno a la mediación de la Virgen creó un contexto donde sus representaciones podían participar de lo sobrenatural, principalmente a través de las historias de fieles y pecadores salvados gracias a su intervención. La literatura mariana del siglo XII define su estatus privilegiado como mediadora por excelencia entre el Hijo de Dios y los hombres, por lo que rogar a la Virgen para conseguir su mediación obtuvo un sustento intelectual al unir la devoción privada con la salvación. Caroline Bynum, Jesus as Mother. Studies in spirituality in High Middle Age, Berkeley, University of California Press, 1982, pp. 115-125; Rachel Fulton, From Judgement to Passion. Devotion to Christ and the Virgin Mary 800-1200, Nueva York, Columbia University Press, 2002, pp. 218-221; Cathy OAKES, Ora Pro Nobis. The Virgin as intercessor in Medieval Art and Devotion, Turnhout, Harvey Miller, 2008, pp. 29-31; Miri RubIn, Mother of God. A history of Virgin Mary, New Haven - Londres, Yale University Press, 2009, p. 27; Étienne SABBE, "Le culte marial et la genèse de la sculpture médiévale", Revue belge d'archéologie et d'histoire de l'art, 20 (1951), pp. 111-112.

${ }^{9}$ Fulberto de Chartres, Sermón IV: De nativitate beatissimae Mariae virginis, PL 141, col. 320. Cfr. Hilda GRAEF, Mary: A History of Doctrine and Devotion, Notre Dame, Ave Maria Press, 2009, pp. 205-206; Fulton, 2002, pp. 219-220.
} 
motivo, las colecciones de milagros son un testimonio excepcional. Aunque, a priori, estas obras están destinadas a promocionar el culto de la Madre de Dios ${ }^{10}$, también son una valiosa fuente para reconstruir el culto que se prestaba a sus efigies, desde su descripción como objetos sagrados y milagrosos hasta diferentes prácticas devocionales ${ }^{11}$. Unos relatos que, además, al estar ilustrados nos proporcionan un amplio muestrario de la cultura visual en la que podemos apreciar lo apuntado por Michael Camille, el cómo se va rompiendo la relación estricta entre María y sus imágenes.

Este artículo centra su atención en la pequeña recopilación de milagros presente en el Miroir Historial, la traducción francesa del Speculum Historiale hecha por Jean de Vignay en el siglo XIV, que cuenta con tres manuscritos iluminados conservados en la Biblioteca Nacional de Francia; el MS français 316 (c. 1333), el MS NAF 15940 (c. 1370-1380) y el MS français 312 (c. 1396). El propósito es analizar los diferentes recursos iconográficos de las miniaturas presentes en dichos códices, su relación con el texto al que acompañan y con la cultura visual coetánea, para esclarecer cómo en los últimos siglos de la Edad Media las imágenes marianas no eran simples representaciones sino substitutas reales y eficaces de su modelo sagrado.

\section{A celle ymage pour grace de aorer: las imágenes milagrosas de la Virgen en el texto del Miroir Historial ${ }^{12}$}

En las últimas décadas, el estudio de las colecciones de milagros ha arrojado nuevas luces sobre la problemática de las imágenes cristianas en el Occidente medieval, corroborando que su culto existía desde tempranas fechas a pesar del rechazo por parte de los teólogos y autoridades intelectuales ${ }^{13}$. A partir del año 1000, con el resurgimiento de la escultura monumental y la búsqueda de una experiencia devocional más

10 Las grandes colecciones de milagros marianos del siglo XIII se caracterizan por su finalidad didáctica y su fomento de la piedad individual. Para dicho fin, los autores añaden su impronta personal, hacen una selección de los relatos y le confieren una estructura interna concreta a sus obras. De esta forma, el mensaje primordial, venerar a la Virgen, llega al lector de una forma más próxima e íntima. Hubert P.J.M. Ahsmann, Le Culte de la Sainte Vierge et la littérature française du Moyen Âge, UtrechtNimègue, Dekker et Van de Vegt, 1930, pp. 80-81; Juan Carlos BAYO, "Las colecciones universales de milagros de la Virgen hasta Gonzalo de Berceo", Bulletin of Spanish Studies, 81 (2004), pp. 849-871; David FloRY, Marian representations in the Miracles Tales of Thirteenth-Century Spain and France, Washington, Catholic University Press, 2000, p. 21; Jesús MonTOYA MARTíNEZ, Las colecciones de milagros de la Virgen en la Edad Media. El milagro literario, Granada, Servicio de Publicaciones de la Universidad de Granada, 1981; André VAuchEz, "Lay people's sanctity in Western Europe: evolution of a pattern (Twelfth and Thirteenth Centuries)", en R. Bulmenfeld-Kosinski y T. Szell (eds.), Images of Sainthood in Medieval Europe, Ithaca-Londres, Cornell University Press, 1991, pp. 28-29.

11 Como parte del mensaje didáctico, los autores de las colecciones de milagros ofrecen múltiples descripciones de prácticas devocionales hacia las imágenes marianas. Jean-Marie SANSTERRE, “Omnes qui coram hac imagine genua flexerint... La vénération d'images de saints et de la Vierge d'après les textes écrits en Angleterre de milieu du XI ${ }^{\mathrm{e}}$ au premières décennies du XIII ${ }^{\mathrm{e}}$ siècle", Cahiers de Civilisation Médiévale, 49 (2006), pp. 257-294; Idem, "Sacralité et pouvoir thaumaturgique des statues mariales ( $\mathrm{X}^{\mathrm{e}}$ siècle-première moitié du XIII ${ }^{\mathrm{e}}$ siècle)", Revue Mabillon, 22 (2011a), pp. 53-77; Idem, "Unicité du prototype et individualité de l'image : la Vierge Marie et ses effigies miraculeuses, approche diachronique d'une croyance entre évidence, rejet et ambiguïté", Degrés, 145-146 (2011b), pp. 1-17; Idem, "L'image 'instrumentalisée' : icônes du Christ et statues de la Vierge, de Rome à l'Espagne des Cantigas de Santa Maria”, en E. Bozoky (ed.), Hagiographie, Idéologie et Pouvoir au Moyen Âge, Turnhout, Brepols, 2012, pp. 463-476.

12 Al no existir una edición crítica del Miroir Historial, los fragmentos reseñados en este artículo corresponderán a la transcripción del MS français 316 de la Biblioteca Nacional de Francia, por ser el más próximo a la traducción de Jean de Vignay. Dichos fragmentos se citarán indicando el folio, la columna y las líneas del texto, añadiendo la referencia de la traducción del Speculum Historiale. La Vierge et le miracle. Le Speculum Historiale de Vincent de Beauvais, M. Tarayre (ed.), París, Honoré Champion, 1999.

13 La posición contra las imágenes de culto se fundamentaba en la imposibilidad de representar lo divino bajo forma humana y en la herencia veterotestamentaria contra la idolatría. AuZÉPY, 1997; BESANÇON, 1994, pp. 208-209; Hans BELTING, Imagen y Culto. Una historia de la imagen antes de la era del arte, Madrid, Akal, 2009, pp. 394-396; BrUBAKER, 1995, pp. 11-15; Herbert Kessler, "Image theory in Ecclesiastic Space" en C. Arrignon, M.H. Debiès, C. Galderesi y E. Palazzo (eds.), Cinquante années d'études médiévales à la confluence de nos disciplines. Actes du colloque organisé à l'occasion du cinquantenaire du CESCM (Poitiers, 1- 4 septiembre de 2003), Turnhout, Brepols, 2005, pp. 295-308; NoBle, 2009, pp. 156-206; Jean-Marie SANSTERRE, 
próxima, los ejemplos son cada vez más numerosos ${ }^{14}$. Si bien una de las imágenes más citadas de dicho momento en la historiografía es la Virgen en majestad de Clermont-Ferrand ${ }^{15}$, no es hasta el siglo XII cuando aumentan considerablemente las crónicas de imágenes marianas que obran milagros u ostentan propiedades taumatúrgicas ${ }^{16}$. Las primeras recopilaciones surgidas en los centros de peregrinación, sumadas a los repertorios universales ya existentes, son el germen de las grandes colecciones de la centuria siguiente, consideradas como un género literario en sí mismo ${ }^{17}$. A diferencia de sus predecesoras, estas obras destacan por estar escritas en lengua vernácula, por existir una clara conciencia de autoría y una estructura interna definida. En el ámbito francés, el primer referente son los Miracles de Nostre Dame, escrita por el monje benedictino Gautier de Coinci antes de 1236, donde las imágenes son protagonistas de los milagros y objeto de reflexión por parte del autor ${ }^{18}$. Así pues, en el relato sobre la conversión de un sarraceno, aconseja a sus colegas eclesiásticos sobre la importancia de la devoción a la imagen de la Virgen:

La dulce dama está alegre cuando la servimos de corazón y cuando honramos su imagen. Bien nos debemos comportar, y honrar su semblanza como lo hicieron estos paganos. Clérigos, esto sabéis, gran error tiene, no es cortés ni sabio, aquel que no limpia sus imágenes y sus altares todas las mañanas. El sarraceno tiene más en sus manos que el clérigo que se niega a limpiar un altar. Por mi alma, deseo que la araña dañe los ojos de aquel que le deje tejer su tela en una imagen de Nuestra Señora [...] Si a la imagen de Nuestra Señora y a la de su Hijo no rezamos devotamente y honramos, como sabios y discretos que debemos ser ¿Por qué un labrador que jamás ha oído hablar de Dios debería honrarla entonces? De sabios es honrar a la Santa Iglesia y sus imágenes. Quien no honra el Crucifijo, jamás creerá en Dios. Y aquel que tenga por amiga a mi dama Santa María, sea viejo o joven, debe rendirle honor cuando la encuentra, puesto que no le agrada que vean su imagen y no se detengan. Aquel que su imagen honra, no puede estar en deshonra, y en el Paraíso será laureado quien a Nuestra Señora en la tierra haya honrado ${ }^{19}$.

"La parole, le texte et l'image selon les auteurs byzantines des époques iconoclastes et posticonoclastes", en Testo e Immagine nell'Alto Medioevo, Spoleto, Centro Italiano di Studi sull'Alto Medioevo, 1994, vol. 1, pp. 1224-1225; SCHMITT, 1987, pp. $272-282$.

${ }^{14}$ Los sínodos carolingios promovieron el uso de los relicarios para mostrar el contenido a los fieles, los cuales a finales del siglo IX van adoptando formas antropomórficas, lo cual favoreció que la imagen participara de lo sobrenatural. Ejemplos como el relicario de la Santa Fe de Conques representan el primer punto de inflexión en el proceso de legitimación de las imágenes, puesto que el componente taumatúrgico comenzó a ser argumento para justificar la presencia de estas representaciones. BELTING, 2009, pp. 399-400; Beate Fricke, Fallen Idols, Risen Saints. Sainte Foy of Conques and the Revival of Monumental Sculpture in Medieval Art, Turnhout, Brepols, 2015, pp. 25-35; Jean-Claude ScHMiтT, 1987, pp. 283-290; André VAUCHEZ, Saints, prophètes et visionnaires. Le pouvoir surnaturel au Moyen Age, París, Albin Michel, 1999, pp. 49-50.

15 La visión de Roberto de Mozat sobre la imagen de la Virgen en majestad de Clermont-Ferrand es otra fuente que revela la importancia del resurgimiento de la escultura monumental y del milagro en la legitimación de las imágenes a partir del año 1000. Belting, 2009, p. 398; Fricke, 2015, pp. 31-41; SANSTERre, 2010a, pp. 50-51; Idem, 2011a, pp. 55-56; SCHMitT, 2002 , p. 185.

16 El fervor religioso surgido en los centros de peregrinación, unido a la difusión de las ideas bizantinas, consolida el poder taumatúrgico de las imágenes marianas y su culto en los albores del año 1200. Giulia BARONE, "Immagini miracolose a Roma alla fine del Medio Evo", en E. Thuno y G. Wolf (eds.), The Miraculous Image in the Late Middle Ages and Renaissance, Roma, L'Erma di Bretschneider, 2003, pp. 123-133; Richard MARKs, Image and Devotion in the Late Medieval England, Stroud, Sutton, 2004; RuBIN, 2009, pp. 228-242.

17 Las primeras recopilaciones escritas en latín partían de un gran corpus común, o bien recogían hechos acontecidos en los santuarios marianos. Aunque había algunos ejemplos en el territorio anglosajón, fue en Francia donde surgieron las más importantes ligadas a Laon, Chartres, Soissons y Rocamadour. Las obras más relevantes del siglo XIII, los Miracles de Nostre Dame de Gautier de Coinci y las Cantigas de Santa Maria de Alfonso X el Sabio, recopilan relatos de ambos repertorios. Silvie BARNAY, El Cielo en la Tierra. Las apariciones de la Virgen en la Edad Media, Madrid, Encuentro, 1999, 46-49; Henri BARRÉ, "Intercession de la Vierge aux débuts du Moyen Âge Occidental”, Bulletin de la Société Française d'Études Mariales, 23 (1966), pp. 77-104; BAYO, 2004; SANSTERRE, $2011 \mathrm{~b}$.

18 Gautier de Coinci es uno de los autores que más reflexiona sobre el culto de las imágenes marianas, definiendo su función y describiendo múltiples prácticas devocionales. Jean-Marie SAnsterre, "La Vierge Marie et ses images chez Gautier de Coinci", Viator, 41 (2010b), pp. 147-178; Fuensanta MuRCiA NiCOLÁs, "Milagro e imágenes de culto. Una nueva cultura visual en los manuscritos de Gautier de Coinci”, Codex Aquilarensis, 28 (2012), pp. 173-176; Idem, Imágenes milagrosas y cultura visual en el siglo XIII. Les Miracles de Nostre Dame de Gautier de Coinci, Aguilar de Campoo, Fundación Santa Maria la Real del Patrimonio Histórico, 2016, pp. 22-27.

19 I Mir 32, versos 86-101, 210-235. Gautier de Coinci, Miracles de Nostre Dame, F. Koenig (ed.), Ginebra, Droz, 1961-1970, vol. III, pp. 26 y 30-32. Cfr. MurCIA Nicolás, 2016, pp. 22-23; Anna RuSSAKOF, Imaging the Miraculous: Miraculous Images of the Virgin Mary in French Illuminated Manuscripts, ca. 1250-ca. 1450, Toronto, Pontifical Institute of Mediaeval Studies, 2019 a, p. 120.

Anuario del Departamento de Historia y Teoría del Arte, vol. 32, 2020, pp. 11-28. ISSN: 1130-5517, eISSN: 2530-3562 
Gautier de Coinci escribe su obra pensando en los lectores laicos, por eso siempre finaliza los milagros con una reflexión personal más didáctica y moralizante que teológica ${ }^{20}$. Este elemento no lo encontramos en el Miroir Historial, que no deja de ser la traducción de una obra enciclopédica, el Speculum Historiale, con una impronta histórica ${ }^{21}$. En la versión latina de Vicente de Beauvais, los milagros de la Virgen se encuentran en el séptimo libro, junto con las crónicas de los reinados de Tiberio y Calígula, la vida de san Juan Bautista, la vida pública de Cristo hasta su muerte, Resurrección y Ascensión, la vida de los fundadores de la Iglesia, la muerte y la Asunción de la Virgen ${ }^{22}$, mientras, en la versión francesa, realizada por Jean de Vignay por encargo de la reina Juana de Borgoña ${ }^{23}$, se encuentran en el octavo libro. Los relatos pertenecen principalmente a los llamados repertorios universales, el propio Vicente cita como fuente el Mariale Magnum, aunque otros ejemplos nos remiten también a los santuarios marianos ${ }^{24}$.

En el Miroir Historial las imágenes son protagonistas de dos tipos de milagros; aquellos que narran algún tipo de profanación, o los que hablan de una imagen que cobra vida. Un ejemplo del primer supuesto es la imagen profanada por un judío, una historia de origen bizantino presente también en otras colecciones como los Miracles de Nostre Dame de Gautier de Coinci o las Cantigas de Santa Maria de Alfonso X el Sabio ${ }^{25}$.

De nuevo en la ciudad de Constantinopla había un judío que miraba la imagen de la bendita Virgen María que figuraba en una pequeña tabla, situada en la pared de la casa de otro. Él pregunta quién era aquella de la figura, y cuando oye que era la bendita Virgen María, se encoleriza y la arranca de la pared. Corre a una casa cercana donde había una letrina y arroja la imagen a su interior. Pronto recibe una muerte atroz que nadie ha visto nunca, créelo, es dado a un espíritu maligno y fue apartado de la mirada de los hombres. Un cristiano recoge la imagen, a la que encuentra entre la basura, la saca fuera, la limpia diligentemente y la cuelga honorablemente en su casa. Y de la tabla en la que la imagen estaba pintada comienza a salir un aceite en honor a la bendita Virgen María, todavía ocurre hoy en día este bello milagro ${ }^{26}$.

Las historias sobre profanaciones de imágenes cobran un especial protagonismo a partir del siglo XIII, en parte debido a la instrumentalización de la Iglesia y del Papado, que las convierte en pruebas y símbo-

20 Uno de los rasgos más distintivos de la escritura de Gautier de Coinci es concluir cada milagro con una reflexión personal sobre las enseñanzas aportadas por el relato. Annette GARNIER, "Écrire selon Gautier", Le Moyen Âge, 110 (2004), pp. 513-537; Marie-Geneviève Grossel, "La digression comme espace de liberté : les 'queues' dans les Miracles de Nostre Dame de Gautier de Coinci”, Senefiance, 51 (2005), pp. 215-228.

21 "La muy bendita Virgen María, después de su Asunción es glorificada por muchos milagros en diversas épocas por diversas partes del mundo. De aquellos milagros queremos incluir brevemente en esta obra algunos dignos de fe, y ratificados por hombres de religión como tales”. BnF, MS français 316, fol. 276r, col. 1, líneas 1-11. Cfr. La Vierge et le miracle, 1999 , p. 37.

22 Monique Paulmier-Foucart y Marie-Christine Duchenne, Vincent de Beauvais et le Grand miroir du monde, Turnhout, Brepols, 2004, p. 95.

23 Juana de Borgoña fue la principal mecenas de Jean Vignay. Gran parte de sus traducciones se realizaron entre los años 1326 y 1350. Sin embargo, varios de sus textos contienen errores, debidos posiblemente a problemas de comprensión del latín. Laurent BRUN y Mattia Cavagna, "Pour une édition du Miroir historial de Jean de Vignay", Romania, vol. 124, 495-496 (2006), pp. 378-428; Claudine Chavannes-Mazel, "Problems in translation, transcription and iconography: The Miroir Historial Books 1-8", en M. Paumier-Foucart, S. Lusignan y A. Nadeau (eds.), Vincent de Beauvais. Intentions et réceptions d'une œuvre encyclopédique au Moyen Âge, París, Vrin, 1990, p. 353; Ludmilla EvdoKIMOVA, "Le Miroir historial de Jean de Vignay et sa place parmi les traductions littérales du XIV siècle", en T. Lassabatère y M. Lacassagne (eds.), Eustache Deschamps, témoin et modèle. Littérature et société politique (XIVe-XVIe siècles), París, Presses de l'Université Paris-Sorbonne, 2008, pp. 178 y 189; Hye-Min LeE, 'Images, culture et mémoire d'histoire: l'iconographie dans l'encyclopédie historique de Vincent de Beauvais", Vincent of Beauvais Newsletter, 33 (2008), p. 3.

24 La Vierge et le miracle, 1999, pp. 17-18.

25 Para la edición y traducción del milagro en Miracles de Nostre Dame; I Mir 13, Gautier de Coinci, 1960-1970, vol. II, pp. 101-104. Cfr. Russakoff, 2019a, p. 119. En el caso de las Cantigas de Santa Maria, Cantiga XXXIIII, Alfonso X el Sabio. Las Cantigas de Santa Maria. Códice Rico T-I-1. Real Biblioteca del Monasterio de San Lorenzo de El Escorial, E. Fidalgo (ed.), Madrid, Testimonio, 2011, vol. 1, pp. 123-124.

$26 \mathrm{BnF}$, MS français 316, fol. 304v, columna 1, líneas 11-23 y columna 2, líneas 1-15. Cfr. La Vierge et le miracle, 1999, pp. 150-153. 
los de la verdadera fe $\mathrm{fe}^{27}$, y al dogma de la Transubstanciación que, si bien hacía alusión a las especies eucarísticas, influye en la creencia de que el personaje puede estar también presente en su imagen ${ }^{28}$. Continuando con esta última idea, están los ejemplos de imágenes vivientes ${ }^{29}$, en cuyo caso también hay que tener en cuenta las nuevas concepciones sobre lo milagroso y su manifestación en el mundo de los hombres, muy especialmente por parte de los escolásticos ${ }^{30}$. Uno de los relatos más conocidos es el que narra cómo un joven entrega un anillo a una estatua de la Virgen:

Entra en la iglesia y va frente a la imagen de la Virgen María, la contempla y se maravilla de su belleza. La saluda arrodillándose devotamente y dice: "Más que aquella que me dio este anillo, tú eres la más bella entre todas las cosas. Por eso renuncio a ella, y de ahora en adelante quiero servirte y amarte, de esta manera espero que me encuentres digno de ser tu amigo". Y así, el joven pone el anillo en el dedo de la imagen a la que se había dirigido, y esta, aprobando el hecho y dando fe, cierra su dedo ${ }^{31}$.

No solo se describe el gesto de la imagen sino que, más tarde, María se aparece al protagonista para exigirle que cumpla su compromiso amoroso ${ }^{32}$, por lo que queda confirmado que ha sido ella la que ha estado detrás del gesto de su estatua. A pesar del carácter histórico de la obra, más destinada a narrar que a aleccionar sobre el culto de la Virgen, Vicente de Beauvais escoge historias muy relevantes en la tradición literaria, recogidas en otras colecciones coetáneas, y que presentan a las imágenes bien como objetos sagrados, cuya profanación es duramente castigada, bien como medios usados por el personaje para manifestarse.

No obstante, también existen referencias, aunque menos que en otras obras, sobre el culto y la devoción a las efigies marianas. Tal es el ejemplo del milagro de una esposa que pide a la Virgen que castigue a la amante de su esposo, pero ella se le aparece para aclararle que no puede, puesto que esta última es una gran devota suya:

Una mujer estaba robándole muy secretamente el marido a otra mujer de su propio lado. Todas las veces que iba a la iglesia, antes de hacer cualquier oración en cualquier lugar, ella se dirigía a la imagen de Nuestra Señora y le recitaba el saludo del ángel. Así pues, la esposa de este hombre que sufría al ver cómo prefería a una adúltera [...]

\footnotetext{
27 La lucha contra las herejías hace que la imagen ya no sea solamente un objeto de devoción, sino también un instrumento que demostraba la hegemonía de la Iglesia. Inocencio III, para mostrar la superioridad de Roma sobre la fe ortodoxa, criticó duramente el culto de los iconos como la Hodegetria, al tiempo que ensalzó la imagen de la Verónica como el verdadero rostro de Cristo. Además de proclamar la posesión del milagroso retrato, dispensó una indulgencia pontificia para todos lo que acudieran a honrarlo. Michele BACCI, "Le rôle des images dans les polémiques religieuses entre l'Église grecque et l'Église latine (XI"-XIII siècle)", Revue belge de philologie et d'histoire, vol. 81, 3-4 (2003), p. 1040; BELTING, 2009, pp. 12-16; Nigel MorGAN, "Text and Images of Marian Devotion in $13^{\text {th }}$ Century England", en W.M. Ormrod (ed.), England in the Thirteenth Century, proceedings of the 1989 Harlaxton Symposium, Stanford, Paul Watkins, 1991, p. 81; ScHMITT, 1987, pp. 300-301; Idem, "Les images d'une image. La figuration du Volto Santo de Lucca dans les manuscrits enluminés au Moyen Âge", en H. Kessler y G. Wolf (eds.), The Holy Face and the paradox of representation, Bolonia, Nuova Alfa Editoriale, 1998, p. 208; VAUCHEZ, 1999, p. 84.

28 García AvilÉs, 2007, p. 324; Murcia NicolÁs, 2016, pp. 17-18; SANSTERre, 2010a, p. 52.

29 Se empleará el término "viviente" para designar aquellas imágenes que, siendo objetos inertes, en un momento dado de la historia cobran vida, moviéndose, hablando o adoptando cualquier actitud humana.

${ }^{30}$ La transformación de la materia se interpretaba en el caso de las imágenes como algo más que una propiedad sobrenatural, también era una forma de conmover al espectador. Alain BouREAU, "Miracle, volonté et imagination : la mutation scolastique (1270-1320)", en Miracles, Prodiges et Merveilles au Moyen Âge, París, Publications de la Sorbonne, 1995, pp. 159-172; ByNuM, 2011, pp. 110-111; CAMILLE, 2000, p. 243.

31 BnF, MS français 316, fol. 280r, columna 1, líneas 35-43; columna 2, líneas 23-32. Cfr. La Vierge et le miracle, 1999 , pp. 54-57.

${ }^{32}$ Las leyendas sobre el prometido de la Virgen tienen un carácter taumatúrgico pero influenciado por el amor cortés, ya que son una cristianización de una historia pagana convertida en un ejemplo de renuncia y abstinencia. Maria Laura ARCANGELI Marenzi, Aspetti del tema della Vergine nella letteratura francese del medioevo, Venecia, Libreria Universitaria Editrice, 1968, pp. 158-160; Paul F. BAUM, "The young man betrothed to a statue", Publications of the Modern Language Association, 34 (1919), pp. 523-579; CAmille, 2000, pp. 256-257; Rubin, 2009, p. 231; Katherine A. SMith, "Bodies of Unsurpassed Beauty: 'Living' images of the Virgin in the High Middle Ages", Viator, 37 (2006), p. 168.
} 
se dirige a la bendita Virgen María y le reza para que abrume con furores celestiales a la mujer que le priva de su marido [...] ella tuvo una visión donde la Virgen bendita se le aparecía en persona con toda la bondad del mundo y le decía: ¿Por qué requieres de mi venganza sobre esta mujer? No puedo hacer nada contra ella, porque cada día ella me recita aquel gozo que me alaga más graciosamente que cualquier otro ${ }^{33}$.

Hay dos elementos importantes que subyacen en este relato, en primer lugar, la ya citada idea de que el personaje está presente en su imagen y, en segundo, la inclusión del "tránsito" bizantino, enunciado por Basilio de Cesárea y retomado por Juan Damasceno, el cual dictamina que el honor prestado a la imagen se dirige a su prototipo ${ }^{34}$. Por lo tanto, esta se convierte en un vínculo que funciona en un doble sentido. Por un lado es un medio empleado por el personaje sagrado para actuar o manifestarse y, por otro, otorga al fiel una experiencia más próxima y cercana, siendo así un elemento fundamental en la devoción pública y privada. La pequeña recopilación del Speculum Historiale no cumple todas las características que tienen las otras colecciones de milagros marianos, pues si bien hay una selección de los relatos y una cierta reivindicación de la autoría, no está dedicado en exclusividad a promocionar el culto mariano puesto que es una obra histórica-enciclopédica. Aunque no podamos equipararla a los Miracles de Nostre Dame o a las Cantigas de Santa Maria, sí es necesario reseñar su contribución a la difusión del discurso favorable a las imágenes. Vicente de Beauvais no las excluye del hecho milagroso, todo lo contrario, las incluye de forma clara y precisa a través de las profanaciones y aquellos ejemplos que cobran vida, siendo tan protagonistas como las propias apariciones marianas. Dicha relevancia no es exclusiva del texto. La traducción al francés realizada por Jean de Vignay en el siglo XIV contará con varios manuscritos iluminados, cuyas miniaturas también reflejan cómo las imágenes habían pasado de ser simples representaciones a ser sustitutas eficaces de la Virgen.

\section{¿Representación de la Virgen o presencia de la Virgen? Las imágenes marianas en la cultura visual de finales de la Edad Media}

En el siglo XIV hay tres conjuntos del Miroir Historial que destacan por la calidad de su ejecución, todos conservados en la Biblioteca Nacional de Francia. El primero es el MS français 316, una copia que solo contiene los ocho primeros libros, el segundo es el conjunto formado por los MSS NAF 15939-15944 y, por último, el grupo de códices français $312-314^{35}$. Sus ilustraciones deben ser contempladas como representaciones mediatizadas, bien por el criterio del artista, bien por el mecenas, pero también por ele-

\footnotetext{
33 BnF, MS français 316, fol. 289r, columna 1, líneas 30-42; fol. 290r, columna 1, líneas 7-12. Cfr. La Vierge et le miracle, 1999, pp. 94-97

${ }^{34}$ La idea del "tránsito" bizantino, aunque enunciada por Basilio de Cesárea, es retomada por Juan Damasceno en su teoría sobre la legitimidad de las imágenes en Bizancio; otorga al icono la función de hacer visible lo invisible y compartir las cualidades de su modelo sagrado. BesAnçon, 1994, p. 175; Jaroslav Pelikan, Imago Dei. The Byzantine Apologia for Icons, New Jersey, Pricenton University Press, 1990, pp. 99-119; Daniel J. SAHAS, Icon and Logos. Sources in Eight-Century Iconoclasm, Toronto, University of Toronto Press, 1986, pp. 176-185; Cornelia A. Tsakidorou, Icons in Time, Persons in Eternity. Orthodox Theology and the Aesthetics of the Christian Image, Farnham-Burlington, Asghate, 2013, pp. 198-205.

35 El MS français 316 es uno de los ejemplares más cercanos a la traducción de Jean de Vignay, cerca de la década de 1330, ilustrado por el Maestro Sub-Fauvel, con la colaboración del Maestro Papeleu. El códice NAF 15490 está fechado en torno a 13701380, localizado en fechas tempranas en la Biblioteca del Duque de Berry. Finalmente el MS français 312 data de 1396 , encargado por el Duque de Orleáns. Elizabeth Morrison y Anne D. HEDEMAN, Imagining the Past in France. History in manuscript painting 1250-1500, Los Ángeles, J. Paul Getty Museum, 2010, p. 151; Russakoff, 2019a, p. 66; Saint Louis: Exposition à Paris, Pierre-Yves Le Pogam et al. (eds.), París, Éditions du Patrimoine (catálogo de la exposición celebrada del 8 de octubre de 2014 al 11 de enero de 2015), 2014, pp. 213-214; Alison Stones, "The Stylistic Context of the Roman de Fauvel, with a Note on Fauvain", en M. Bent y A. Wathey (eds.), Fauvel Studies: Allegory, Chronicle, and Image in Paris, Bibliothèque Nationale de France, MS français 146, Oxford, Clarendon Press, 1998, pp. 529-567. Todos estos códices están disponibles en la plataforma Gallica, propiedad de la Biblioteca Nacional de Francia.
} 
mentos de una cultura visual que eclosiona a finales del siglo XII en torno a las imágenes. Por dicho motivo se tendrá en cuenta la relación con el texto al que acompañan, así como la que guardan con otros ejemplos anteriores o coetáneos.

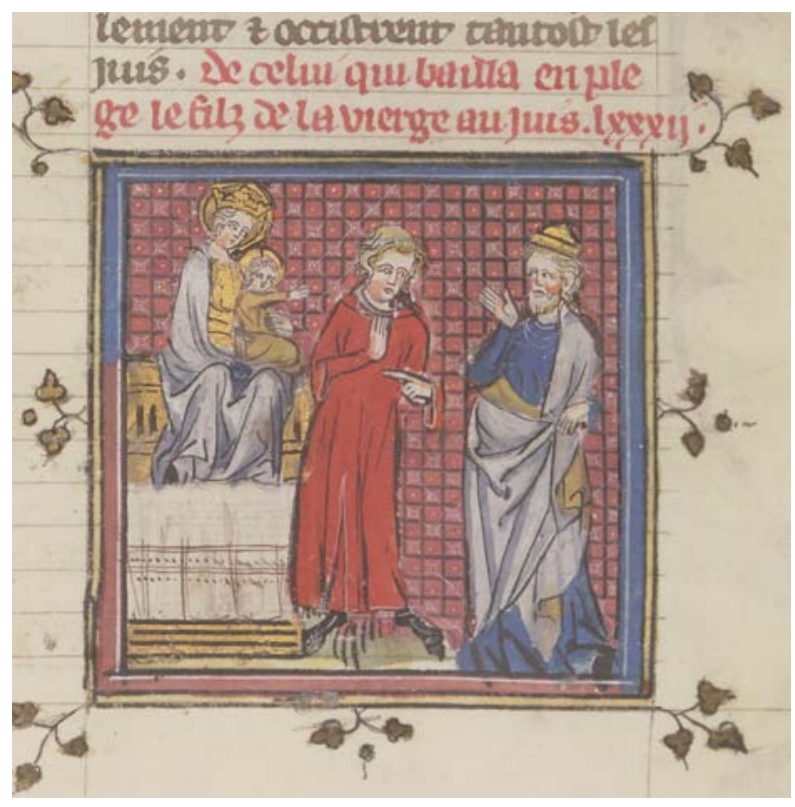

Fig. 1. El milagro del prestamista judío. Vicente de Beauvais, Miroir Historial trad. Jean de Vignay, París, Biblioteca Nacional de Francia, MS français 316, fol. 276r (c. 1333).

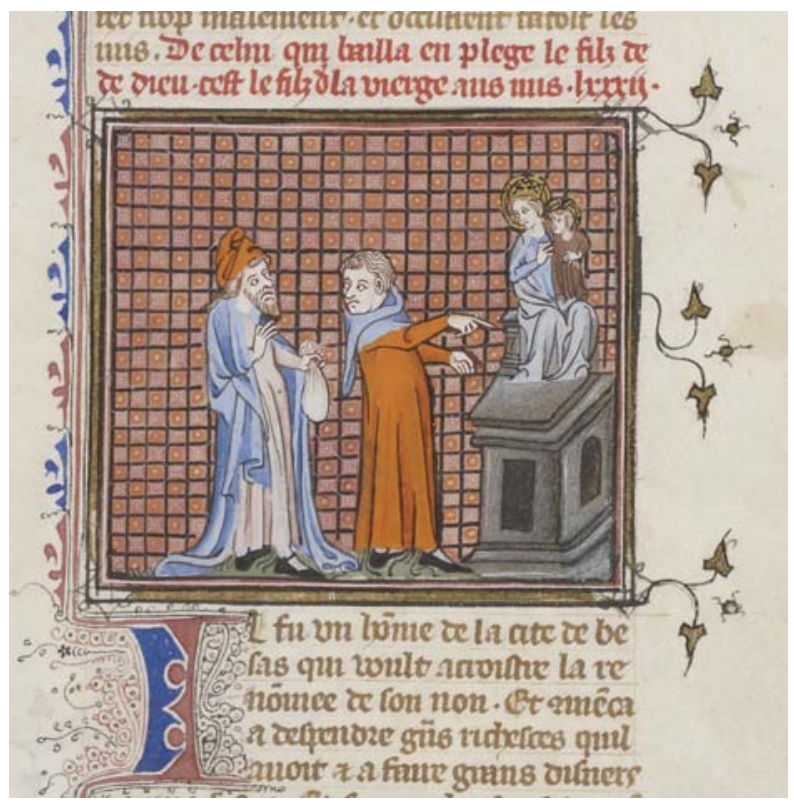

Fig. 2. El milagro del prestamista judío. Vicente de Beauvais, Miroir Historial trad. Jean de Vignay, París, Biblioteca Nacional de Francia, MS NAF 15940, fol. 69r (c. 1370-1380).

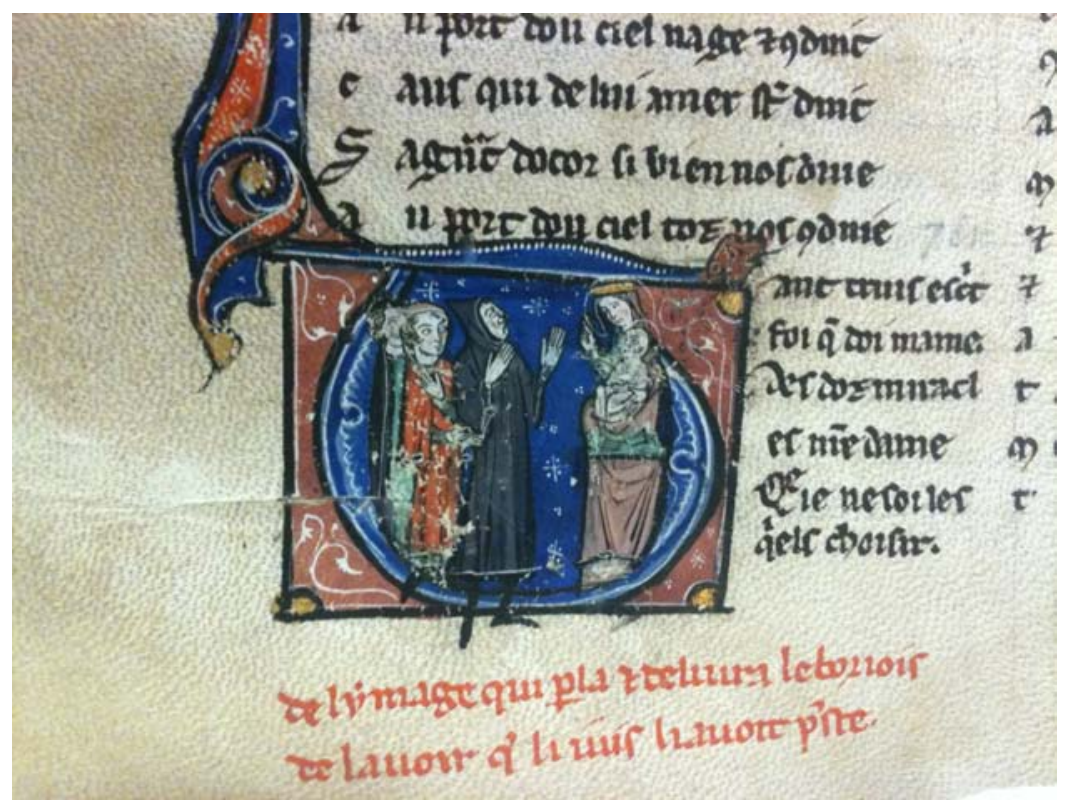

Fig. 3. El milagro del prestamista judío. Gautier de Coinci, Miracles de Nostre Dame, Bruselas, Biblioteca Real Alberto I, ms. 10747, fol. 159v (c. 1260-1280). 
Uno de los relatos cuenta la historia de un comerciante cristiano que demanda un préstamo a un judío, dejando como garantía su promesa hecha frente a una imagen de la Virgen con el Niño ${ }^{36}$, la cual aparece como una talla escultórica nimbada sobre un altar en los manuscritos français 316 y NAF 15490 (figs. 1 y 2). Muy común en los manuscritos de colecciones marianas desde el siglo XIII (fig. 3) ${ }^{37}$, esta fórmula demuestra la independencia que habían adquirido las imágenes, motivada por los debates teológicos pero también por la rehabilitación de la materialidad sensible ${ }^{38}$, que otorgaba un estatus sacro a los objetos inertes $^{39}$, haciendo que desaparezcan los límites con su modelo. Ambas figuras aparecen nimbadas, no solo para demostrar su carácter sagrado sino para señalar que tanto María como su hijo están presentes en aquello que les representa. Por otro lado, y no menos relevante, la devoción privada proporcionaba un espacio de proximidad y cercanía con lo divino. Una experiencia individual, también emocional, en la que las imágenes marianas se presentan como elementos indispensables ${ }^{40}$. Otra de las historias recogidas en el Miroir Historial es la del clérigo que, a pesar de todos sus defectos, todos los días saludaba a la Virgen en la iglesia. El milagro ocurre cuando, tiempo más tarde, este enferma y ella se aparece junto a su cama para sanar$10^{41}$. En el manuscrito français 316, el relato visual comienza precisamente con una escena de devoción privada para yuxtaponerla con la aparición mariana (fig. 4), creando una relación causa-efecto, es decir, una oración ante la imagen desencadena una acción concreta. No menos llamativo es cómo está representada. A diferencia de los ejemplos anteriores, aquí no está sobre el altar, ha perdido su apariencia de objeto y se nos presenta como una figura casi animada, haciendo difícil distinguir si estamos ante una imagen o la Virgen en persona, un rasgo que también comparte la escena de devoción del ya citado relato de las dos mujeres en el mismo códice (fig. 5).

36 Más tarde, el judío niega la devolución del importe y el cristiano le obliga a repetir su acusación delante de la imagen, cuando entonces la figura del Niño cobra vida para amonestar al prestamista, el cual, finalmente se convierte al cristianismo. La Vierge et le miracle, 1999, pp. 38-43. Sobre la representación de este milagro en los Miracles de Nostre Dame, Fuensanta Murcia NiCOLÁs, "Ilustrando milagros: las imágenes milagrosas de la Virgen en los manuscritos del siglo XIII de Gautier de Coinci", Tesis doctoral, Murcia, Universidad de Murcia, 2015, pp. 143-147; Anna Russakoff, "The Jew, the Merchant and a Miraculous Image: Comparative Iconography in Gautier de Coinci's Miracles de Nostre Dame Manuscripts", en Jewish Identity and Comparative Studies/Judéité et comparatisme, Amiens, Presses du Centre d'Études Médiévales de Picardie, 2019b, pp. 387-397.

37 El motivo de la imagen nimbada sobre el altar, normalmente presidiendo la escena, es uno de los más frecuentes en las miniaturas de las colecciones de milagros marianos del siglo XIII, tanto en los manuscritos de Gautier de Coinci como en el Códice Rico de las Cantigas de Santa Maria. García AviLÉs, 2007; Idem, "Este rey tenno que enos idolos cree: imágenes milagrosas en las Cantigas de Santa María”, en L. Fernández Fernández y J.C. Ruiz Souza (eds.), Alfonso X el Sabio. Las Cantigas de Santa Maria. Códice Rico MS T-I-1. Real Biblioteca del Monasterio de San Lorenzo de El Escorial, Madrid, Testimonio, 2011, vol. 2, pp. 521-559; Fuensanta Murcia Nicolás 2012; Idem, 2016; Rocío SÁNCHEZ AMEJEIRAS, "Del Salterio al Marial: sobre las "fuentes" de las imágenes de los códices de las historias de las Cantigas de Santa Maria”, Alcanate. Revista de Estudios Alfonsíes, $\mathrm{n}^{\circ} 8$ (2012-2013), pp. 55-80.

38 El dogma de la transubstanciación ratificaba la presencia de lo divino en un objeto inerte, previamente consagrado. Si Cristo estaba presente en las sustancias eucarísticas, este mismo razonamiento se aplicó a las imágenes, las cuales debido a esa "presencia" podían ostentar propiedades milagrosas. BYNUM, 2011, p. 218; BoulnOIs, 2008, p. 267; GARCÍA AvILÉs, 2011, p. 526.

39 CAmille 2000, p. 223-224; García Avilés, 2010, p. 35; VAuchez, 1999, p. 54.

${ }^{40}$ La imagen aparece como mediadora y agente del milagro, pero también como elemento fundamental en la devoción mariana. Este rasgo es muy reseñable en el texto de Gautier de Coinci, el cual por sus características formales, permite un mayor desarrollo lírico. En cuanto al discurso visual, es importante destacar el hecho de que los artistas incluyen a las imágenes en las miniaturas incluso sin existir una referencia textual. GARCíA AvILÉs, 2011; MurCIA NicolÁs, 2012; Idem, 2016.

41 La Vierge et le miracle, 1999, pp. 44-47. 

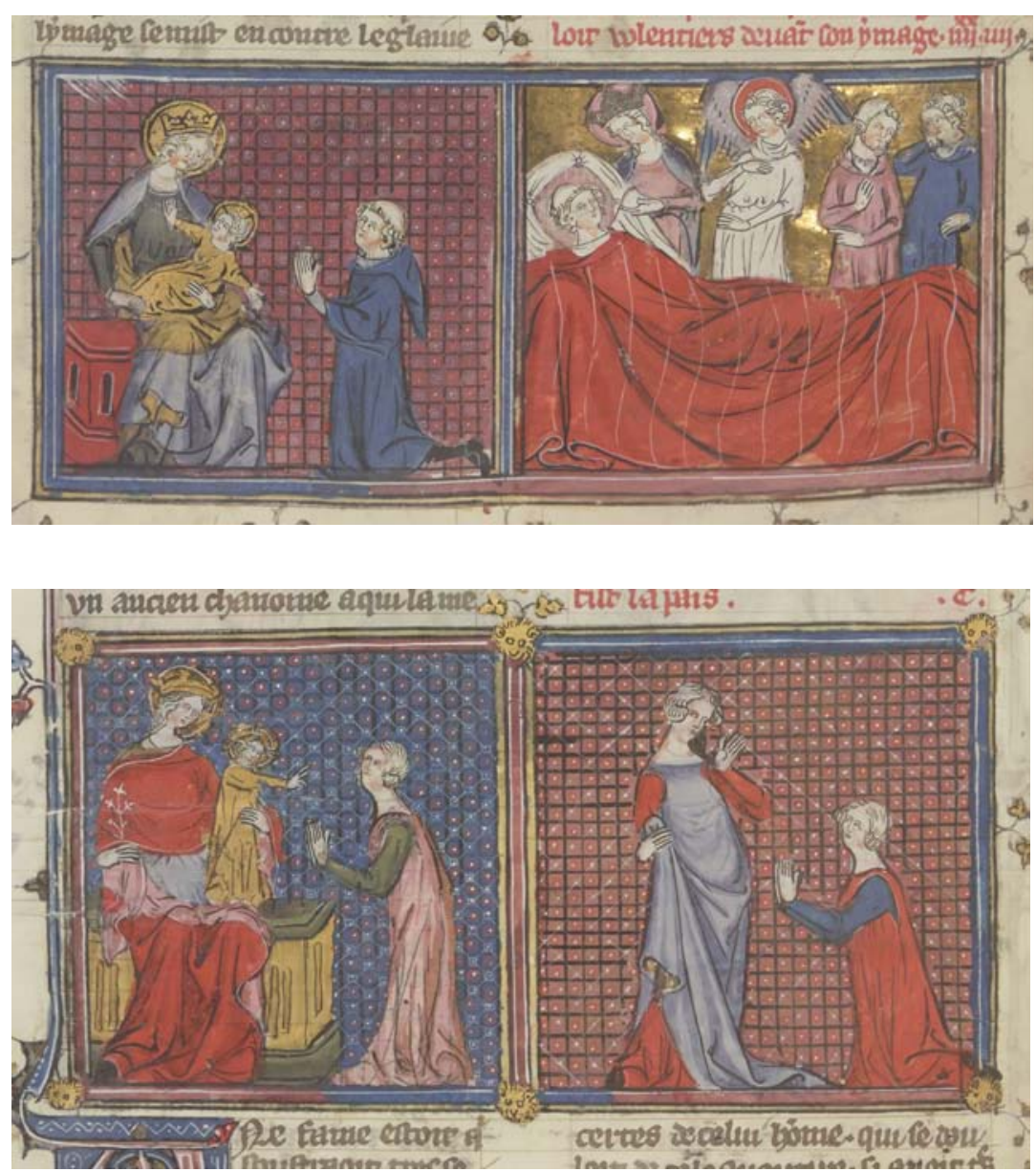

Fig. 4. El milagro del clérigo enfermo. Vicente de Beauvais, Miroir Historial trad. Jean de Vignay, París, Biblioteca Nacional de Francia, MS français 316 , fol. 277v (c. 1333).

Fig. 5. El milagro de las dos mujeres. Vicente de Beauvais, Miroir Historial trad. Jean de Vignay, París, Biblioteca Nacional de Francia, MS français 316, fol. 289v (c. 1333).

Esta confusión que será tan clara en el contexto milagroso, también puede aparecer fuera del mismo, incluso en fechas relativamente tempranas. Un claro ejemplo es uno de los vitrales de la Catedral de Le Mans (fig. 6), fechado antes de $1258^{42}$. El conjunto está dedicado a la vida de la Virgen y sus milagros. En la segunda lanceta, se narra el milagro de la abadía de Evron, protagonizado por una imagen que encontramos en la parte superior (fig. 7) ${ }^{43}$, emplazada en un altar adornado con dos cirios, un espacio sagrado, pero, una vez más, su apariencia no remite a un objeto sino a una figura humanizada. Lo interesante de este vitral no es tanto ver este esquema en el relato de un milagro, sino que se aplique en la escena litúrgica de la parte inferior (fig. 8), donde una ceremonia de la Eucaristía se yuxtapone con la Adoración de los Magos. Marcello Angheben ha estudiado detalladamente la relación teológica entre ambas escenas y el rol litúrgico de la Virgen ${ }^{44}$, lo cual explicaría el por qué los Magos se postran ante su figura con el Niño que, a su

42 Maria GodlevsKaYA, "Les vitraux du XIII' siècle de la cathédrale du Mans. Aspects iconographiques et stylistiques", Tesis doctoral, Poitiers, Université de Poitiers, 2013, pp. 289-299. Cfr. Les vitraux du Centre et des Pays de la Loire, París, Éditions du CNRS, 1981, pp. 241-257.

43 Marcello AngheBen, "Résonances sacramentelles, dévotionnelles et sensorielles des images : la Vierge à l'Enfant et la Crucifixion sur les vitraux de la cathédrale du Mans", en S.D. Daussy y N. Reveyron (eds.), L'Église lieu de performances: In Locis competentibus, París, Picard, 2016, pp. 167-169.

44 Marcello Angheben, "La Vierge à l'Enfant comme image du prêtre officiant. Les exemples des peintures romanes des Pyrénées et de Maderuelo", Codex Aquilarensis, 28 (2012), pp. 29-74; Idem, "Les statues mariales pyrénéennes et la progressive assimilation de la Vierge à l'Enfant au prêtre officiant", en S. Brouquet (ed.), Sedes Sapientiae. Vierges Noires, culte marial et pèlerinages en France méridionale, Toulouse, Presses universitaires du Midi, 2016, pp. 19-45. 
vez, está situada de nuevo en un altar. Esta escena nos remite a los dramas litúrgicos protagonizados por los Tronos de Sabiduría ${ }^{45}$, en los que los sacerdotes asumen el papel de los tres oferentes. En esta escena se muestra un ritual similar a excepción del motivo de la imagen, pues aunque no ha perdido su contexto litúrgico, el altar decorado con cirios, sí la apariencia escultórica inerte.

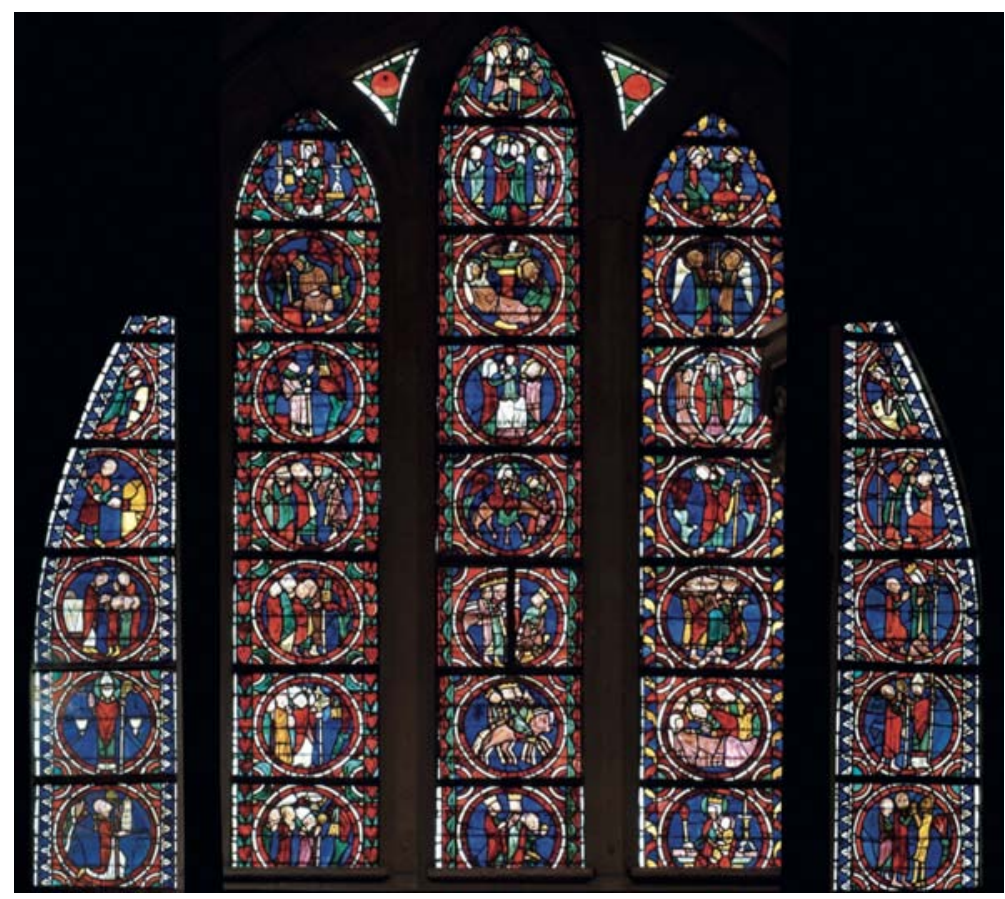

Fig. 6. Vitral de la Abadía de Evron. Catedral de Le Mans, primer deambulatorio, vano 105 (a. 1258).

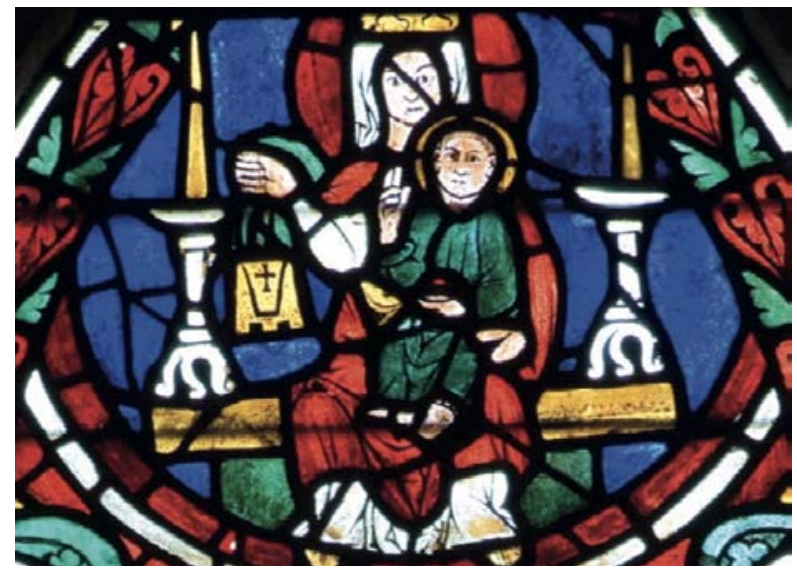

Fig. 7. Vitral de la abadía de Evron. Catedral de Le Mans, primer deambulatorio, vano 105 (a. 1258). Escena superior, segunda lanceta. Detalle de la imagen de la Virgen.

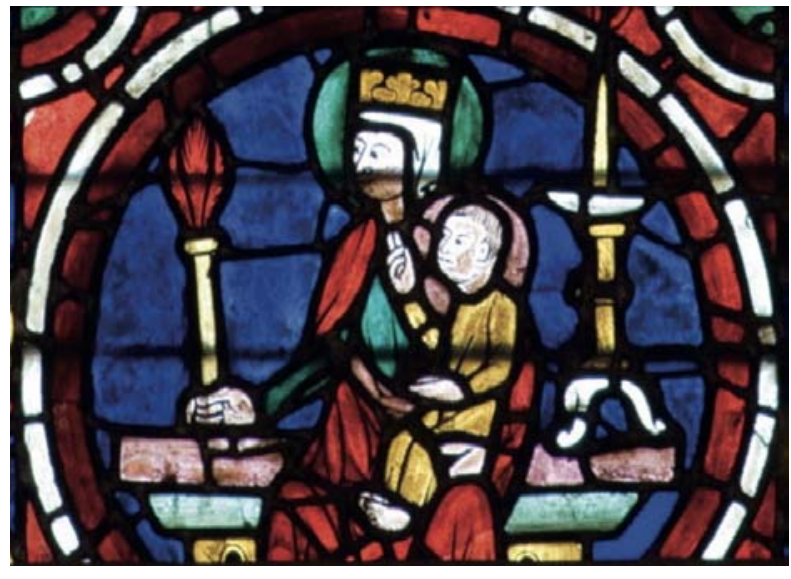

Fig. 8. Vitral de la abadía de Evron. Catedral de Le Mans, primer deambulatorio, vano 105 (a. 1258). Parte inferior. Detalle de la imagen de la Virgen de laAdoración de los Magos.

45 Michelle Pradalier-Schlumberger, "L'image de la Vierge de la Chandeleur au XIII" et au XIVe siècle", en De la création à la restauration. Travaux offerts à Marcel Durliat, Toulouse, Atelier d'histoire de l'art méridional, 1992, pp. 341-350; Catherine VINCENT, Fiat Lux. Lumière et luminaires dans la vie religieuse en Occident du XIII e au début du XVIe siècle, París, Cerf, 2004, pp. 
En algunos de los manuscritos de Gautier de Coinci es común encontrar este tipo de imágenes "hipernaturalizadas" 46 , como en el citado milagro del clérigo enfermo. Si atendemos a las miniaturas del MS français 22928 de la Biblioteca Nacional de Francia (fig. 9), hay un precedente claro de la representación del Miroir Historial; la figura de la Virgen con el Niño, al mismo nivel que el protagonista en una escena de devoción privada, y su yuxtaposición con la aparición mariana ${ }^{47}$. Aunque también aparecen sin existir una referencia textual. Los artistas que ilustran el códice conservado en la Biblioteca de Besançon (MS 551) plasman esta idea aunque Gautier de Coinci no haga alusión alguna. Así ocurre en los milagros de la noble mujer de Roma y el de la abadesa encinta. En ambos, al contrario que en el clérigo enfermo, el autor solo las describe como muy devotas de la Virgen ${ }^{48}$. Sin embargo en las miniaturas que abren las dos historias (figs. 10 y 11), los artistas han plasmado esa idea usando una escena de devoción con una imagen "casi viviente". El uso de estos esquemas visuales indica que las imágenes marianas eran comprendidas como algo más que un objeto sagrado y que eran tratadas como si fueran la Virgen en persona.

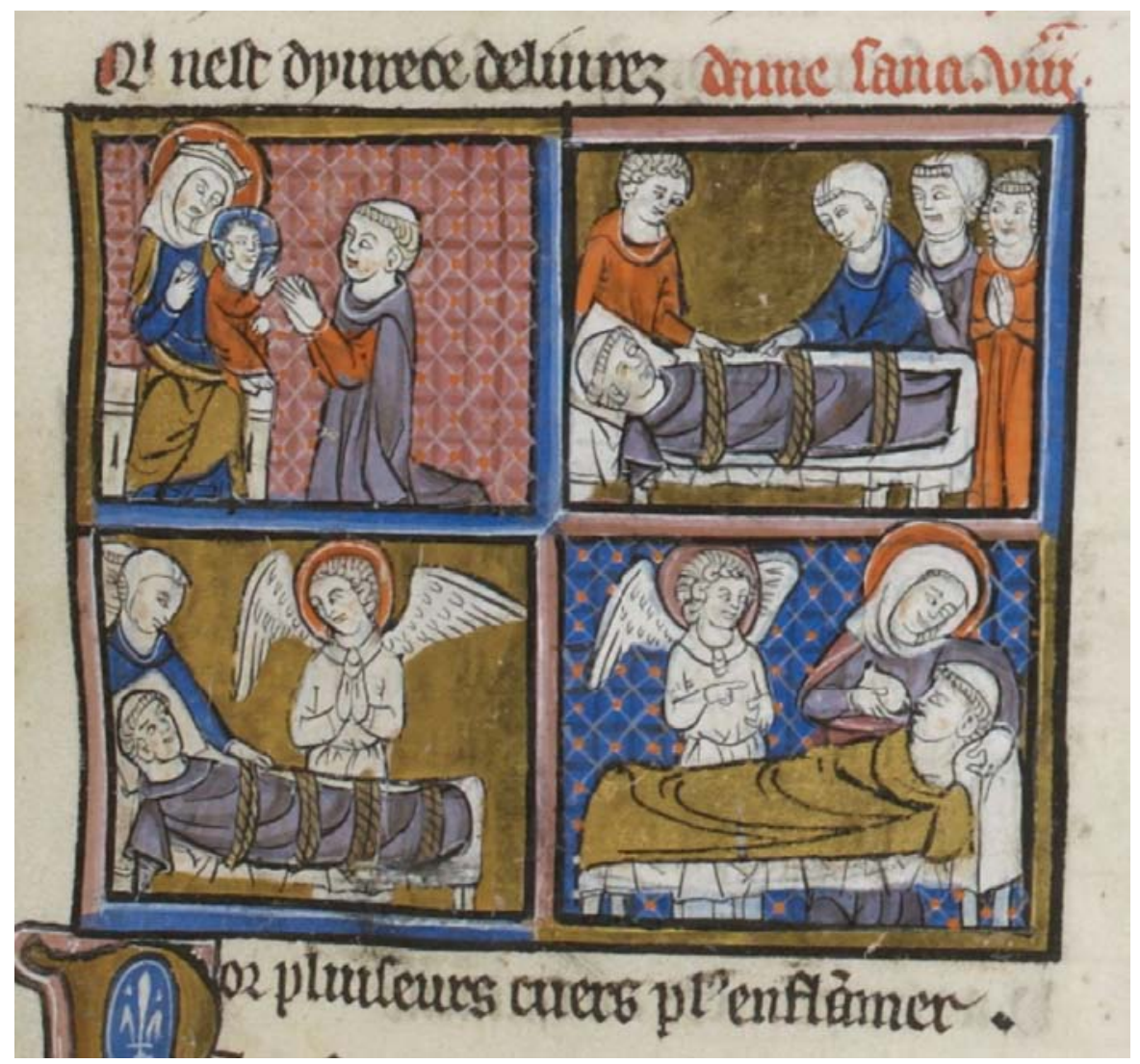

Fig. 9. El milagro del clérigo enfermo. Gautier de Coinci, Miracles de Nostre Dame, París, Biblioteca Nacional de Francia, MS français 22928, fol. 80r (c. 1280-1300).

46 Los términos "imágenes hipernaturalizadas" o "imágenes casi vivientes" se emplean para designar la representación de ciertas imágenes que, sin llegar a cobrar vida, presentan una apariencia y actitud que no corresponden con la de un objeto escultórico o pictórico, tales como tener la misma escala que el protagonista o estar situadas a un mismo nivel de realidad.

${ }^{47}$ El desarrollo de la narrativa visual permitió crear este tipo de discursos en los que hay una relación directa entre la devoción a la imagen y la intervención mariana. MuRCiA NiCOLÁs, 2012, pp. 178-179; Idem, 2016, pp. 40-43.

48 Milagro de la noble mujer de Roma: I Mir 18, Gautier de Coinci, vol. 2, pp. 130-157; milagro de la abadesa encinta: I Mir 20, Gautier de Coinci, vol. 2, pp. 181-196. Cfr. Gautier de Coinci, Los milagros de Nuestra Señora, J. Montoya Martínez (ed.), Barcelona, P.P.V., 1989, pp. 76-97. 


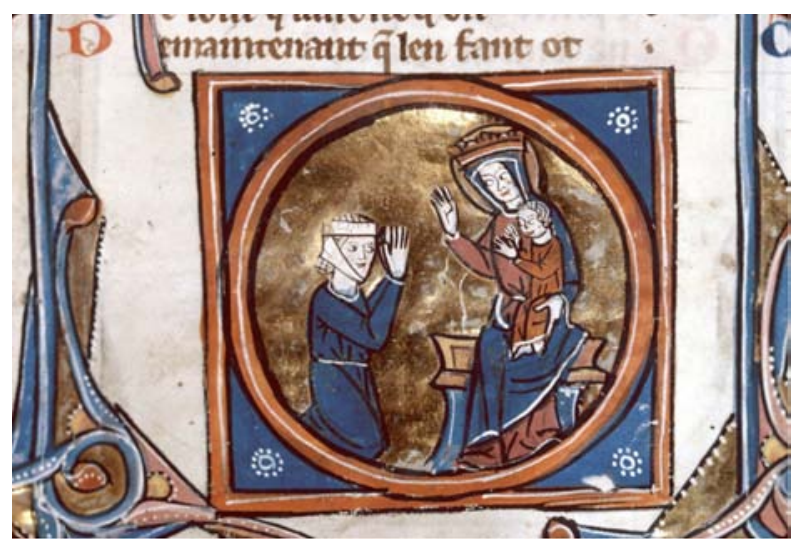

Fig. 10. El milagro de la noble mujer de Roma. Gautier de Coinci, Miracles de Nostre Dame, Biblioteca municipal de Besançon, ms. 551, fol. 35r (c. 1270).

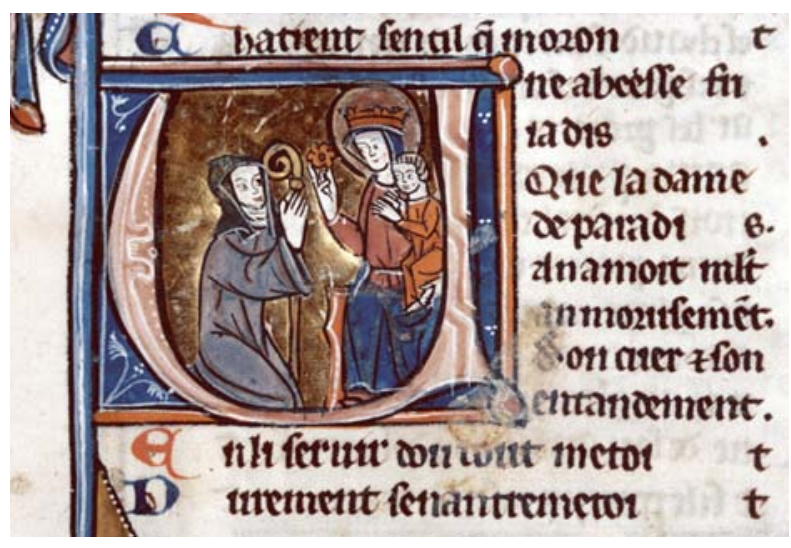

Fig. 11. El milagro de la abadesa encinta. Gautier de Coinci, Miracles de Nostre Dame, Biblioteca municipal de Besançon, ms. 551, fol. 41r (c. 1270).

La ilustración del Miroir Historial coincide con el punto álgido de los milagros marianos, el siglo XIV ${ }^{49}$. Jean-Marie Sansterre señala tres factores que condicionan la evolución del culto a las imágenes de la Virgen en ese momento ${ }^{50}$. El primero es su promoción en los espacios públicos por parte de los laicos, como ocurre con el caso de las cofradías ${ }^{51}$. El segundo es el aumento de experiencias místicas, que si bien en siglos anteriores tenían como foco de atención las representaciones del Crucificado, ahora también se centran en las de la Virgen $^{52}$. Y, finalmente, la existencia de un proceso de individualización, es decir, que cada imagen es tratada de forma única, no como representación, sino como si fuera una personalización ${ }^{53}$. Este interesante fenómeno está recogido en críticas de eclesiásticos, generalmente a peregrinos, a los que les reprochan dicho tratamiento. Uno de los ejemplos más relevantes analizado por Jean-Marie Sansterre es el del santuario de Walsingham, conocido por la devoción que despertaba la efigie de la Virgen allí conservada ${ }^{54}$. Tomás Moro llegó a decir sobre los devotos que "se equivocan al pensar que la imagen de Walsingham es Nuestra Señora en persona" 55.

49 Nicolas Balzamo, Les miracles dans la France du XVI siècle, París, Les Belles Lettres, 2014; Idem, "Objets incertains et croyances ambiguës. La Vierge et ses images miraculeuses dans le catholicisme moderne (XVI ${ }^{\mathrm{e}}-\mathrm{XVII}{ }^{\mathrm{e}}$ siècles)", Histoire, Monde \& Cultures religieuses, 38 (2016), pp. 87-103; Francesca ESPAÑOL BERTRAN, "El milagro y su instrumento icónico. La fortuna de las imágenes sagradas en el ámbito peninsular", Codex Aquilarensis, 29 (2013), pp. 117-134; Felipe PEREDA, Las imágenes de la discordia. Política y poética de la imagen sagrada en la España del cuatrocientos, Madrid, Marcial Pons, 2007; Jean-Marie SANSTERRE, "Vivantes ou comme vivantes : l'animation miraculeuse d'images de la Vierge entre Moyen Âge et époque moderne", Revue de l'histoire des religions, vol. 232, 2 (2015), pp. 155-182.

50 SANSTERre, $2011 \mathrm{~b}$.

51 Sheila BARKER, "Miraculous Images and the Plagues of Italy, c. 590-1656", en S. Cardarelli y L. Fenelli (eds.), Saints, Miracles and the Image. Healing Saints and Miraculous Images in the Renaissance, Turnhout, Brepols, 2018, pp. 29-52; André VAUCHEZ, "Culte des saints et pèlerinages aux derniers siècles du Moyen Âge (v.1200-v.1500) : essai de bilan historiographique", en L. Bertazzo, D. Gallo, R. Michetti y A. Tilatti (eds.), Arbor ramosa. Studi per Antonio Rigon da allievi, amici, colleghi, Padua, Centro Ctudi Antoniani, 2011, pp. 49-66.

52 Belting, 2009, pp. 555-568; Jeffrey F. HAmburger, The Visual and the Visionary. Art and Female Spirituality in Late Medieval Germany, Nueva York, Zone Books, 1998; Barbara NewMAN, "The Visionary Texts and Visual Worlds of Religious Women", en J. Hamburger y S. Marti (eds.), Crown and Veil. Female Monasticism from the Fifth to the Fifteenth Centuries, Nueva York, Columbia University Press, 2008, pp. 151-171.

53 Jean-Marie SANSTERRE, "Entre sanctuaires et images : individualisation locale et unicité du même personnage céleste (XII"première moitié du XVI $\mathrm{X}^{\mathrm{e}}$ siècle)", en N. Balzamo y E. Leutrat (eds.), L'image miraculeuse. Théories, pratiques et représentations dans le monde chrétien (XIVe-XVII siècles), Rennes, Presses universitaires de Rennes (en prensa).

54 Ibidem. El mismo autor trata de forma amplia el caso de este santuario en su próximo libro Les images sacrées en Occident au Moyen Âge: histoire, attitudes, croyances, Madrid, Akal, 2020 (en prensa).

55 Frank Mitjans, "Thomas More's Veneration of Images, Praying to Saints and Going on Pilgrimages", Thomas More Studies, 3 (2008), pp. 64-69. 
Estos factores explicarían la normalización de representar a las imágenes no como objetos sino como personificaciones de la Virgen. Más allá de las escenas de devoción privada analizadas anteriormente, esta excesiva individualización es más llamativa en el caso de la imagen viviente, un detalle importante si atendemos a la norma que se empleaba en el siglo XIII. Aunque existen excepciones ${ }^{56}$, cuando una estatua cobraba vida mantenía su apariencia para remarcar aún más esa animación. En esta línea, en las ilustraciones del milagro del novio de la colección de Gautier de Coinci y en las Cantigas de Santa Maria (figs. 12 y 13), el protagonista aparece entregándole el anillo a la estatua de la Virgen que, siguiendo el relato, estaba emplazada en la puerta de una iglesia ${ }^{57}$. Si bien el texto del Miroir Historial no difiere mucho en la trama argumental, solo que la imagen está en el interior ${ }^{58}$, por contra la diferencia está en las miniaturas; puesto que la figura de la Virgen ha perdido completamente su apariencia de estatua, y se sitúa al mismo nivel que el joven (figs. 14 y 15 ).

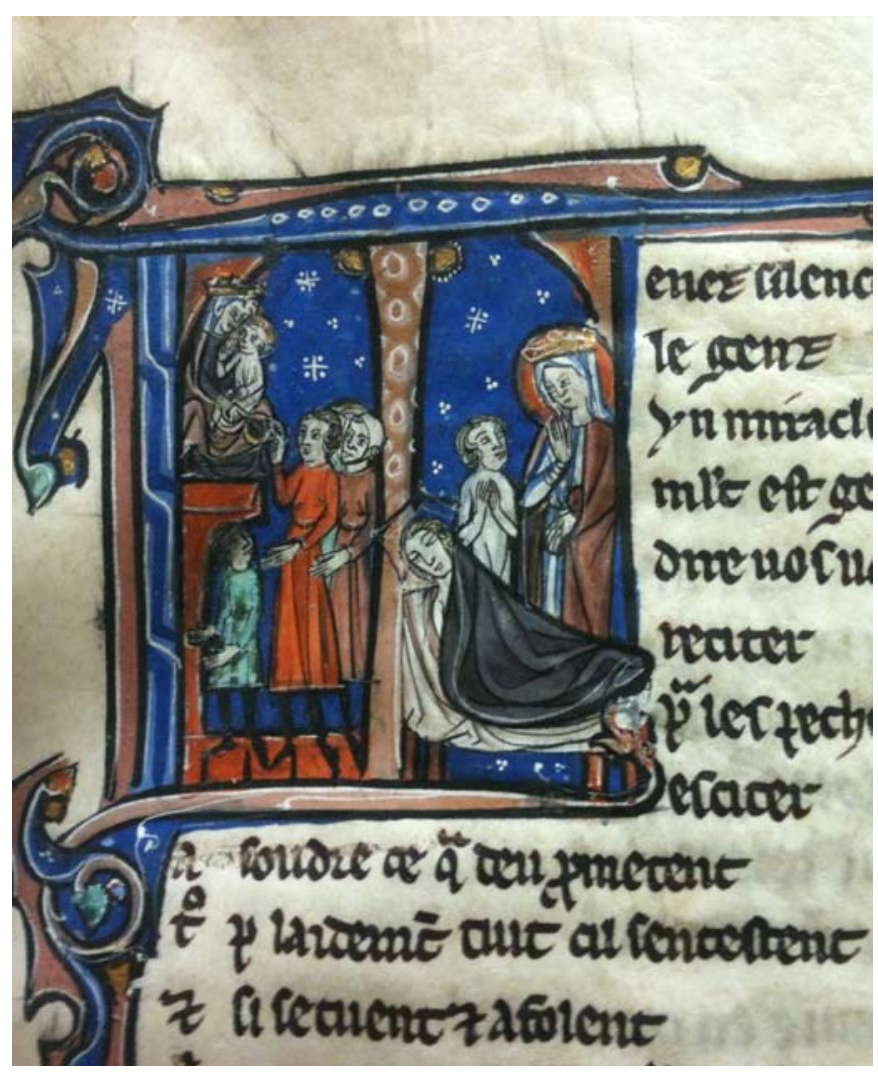

Fig. 12. El milagro del novio. Gautier de Coinci, Miracles de Nostre Dame, Bruselas, Biblioteca Real Alberto I, ms. 10747, fol. 52 r (c. 1260-1280).

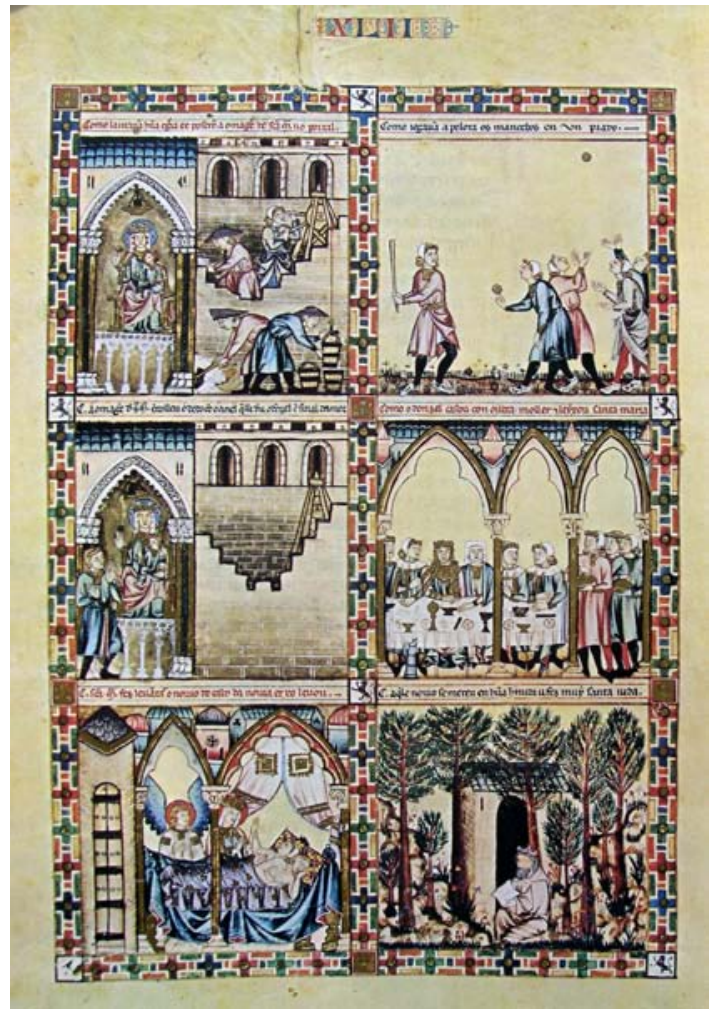

Fig. 13. El milagro del novio. Alfonso X el Sabio, Cantigas de Santa Maria, Real Biblioteca del Monasterio de San Lorenzo de El Escorial, ms. T-I-1, fol. 61v (c. 1280-1284).

\footnotetext{
56 Dentro de los manuscritos iluminados del siglo XIII destaca como excepción el ejemplar conservado en la Biblioteca de Besançon (MS 551) de la colección de Gautier de Coinci. A pesar de las carencias en su ejecución artística, es el más interesante a nivel iconográfico, puesto que posee una amplia gama de recursos icónicos sobre las imágenes milagrosas, especialmente en el caso de aquellas que cobran vida. MurCia Nicolás, 2012, pp. 180 y 184; Idem, 2016, pp. 59-61; Anna RusSAKOFF, "The role of the image in illustrated manuscript of 'Les Miracles de Nostre Dame' by Gautier de Coinci”, Manuscripta, 47-48 (2003-2004), pp. 135-144; Idem, 2019a, pp. 37-41.

57 I Mir 21, Gautier de Coinci, vol. 2, pp. 198-199. Cfr. Vierge et Merveille. Les miracles de Nostre Dame narratifs au Moyen Âge, P. Kunstmann (ed.), París, Union Générale d’Éditions, 1981, pp. 87-89. Cantiga XLII, Alfonso X el Sabio, 2011, pp. 137-140.

58 La Vierge et le miracle, 1999, p. 55.
} 


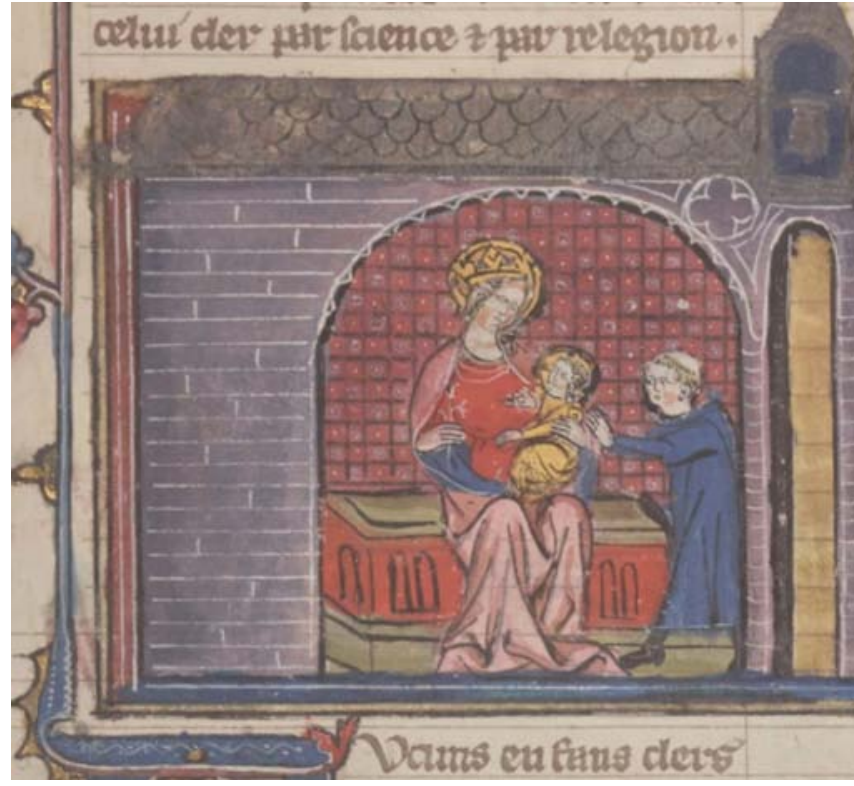

Fig. 14. El milagro del novio. Vicente de Beauvais, Miroir Historial trad. Jean de Vignay, París, Biblioteca Nacional de Francia, MS français 316, fol. 280r (c. 1333).

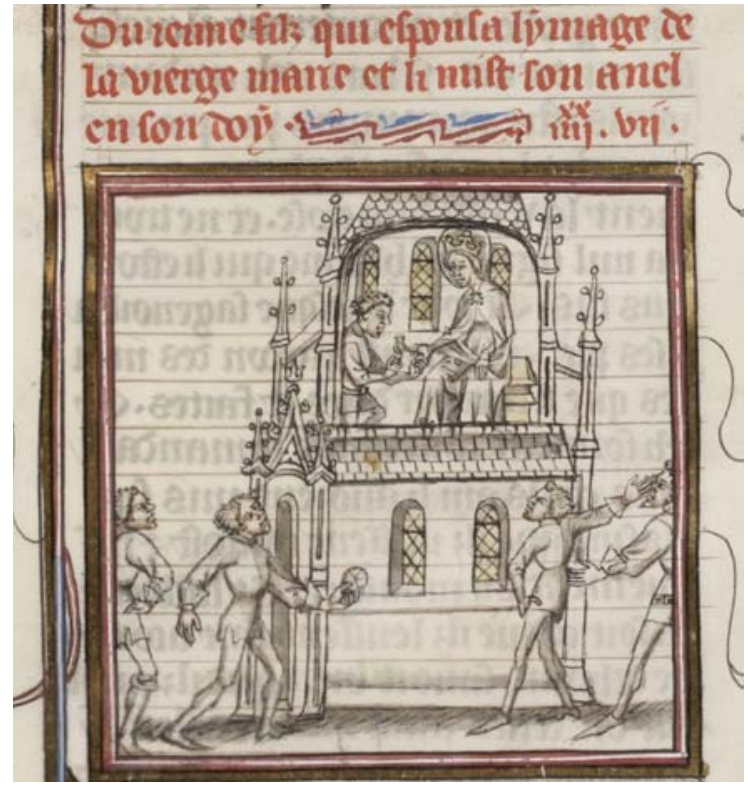

Fig. 15. El milagro del novio. Vicente de Beauvais, Miroir Historial trad. Jean de Vignay, París, Biblioteca Nacional de Francia, MS français 312, fol. 329v (c. 1396).

Otro conocido ejemplo es el milagro del pintor, a quien el Diablo amenaza por la pintura que estaba haciendo de él. Más tarde, viendo que el protagonista no había modificado su retrato, lo tira del andamio para arrojarlo al vacío y "entonces como si sintiera lo que estaba ocurriendo, eleva sus manos y su corazón a la imagen de la señora de la gracia, que por tal maravilla, sujetó su mano para sostenerlo y ayudarlo. Así la imagen lo cuidó" "59. La imagen viviente, igual que en el caso anterior, no se muestra como representación pictórica sino como si fuera la Virgen en persona (fig. 16), e incluso en el MS français 312 aparece sin la figura del niño (fig. 17) ${ }^{60}$, reforzando aún más la creencia de que ella está presente en aquello que la representa. Esta característica aparece también en los milagros de la imagen lapidada y la escultura atacada por un grupo de sarracenos (figs. 18 y 19) ${ }^{61}$. El hecho de presentarlas como figuras "casi vivientes" va más allá de la individualización, indica que profanar una imagen es como agredir a la propia María. Así pues, las diferentes fórmulas iconográficas presentes en los manuscritos del Miroir Historial son similares, uniformidad que responde a unas ideas sobre las imágenes milagrosas cada vez más asentadas en la mentalidad medieval. El ejemplo de las efigies marianas sirve de muestra para comprobar cómo la imagen era algo más que un objeto de culto, dispuesto sobre un altar coronado con un nimbo. Cumplía, además, una función importante, hacer más próxima y más evidente la presencia de María en la experiencia religiosa.

\footnotetext{
59 BnF, MS français 316, fol. 293r, columna 1, líneas 3-11. Cfr. la Vierge et le miracle, 1999, p. 107.

60 RussaKofF, 2019a, pp. 67-71.

61 Ibidem, pp. 71-77.
} 


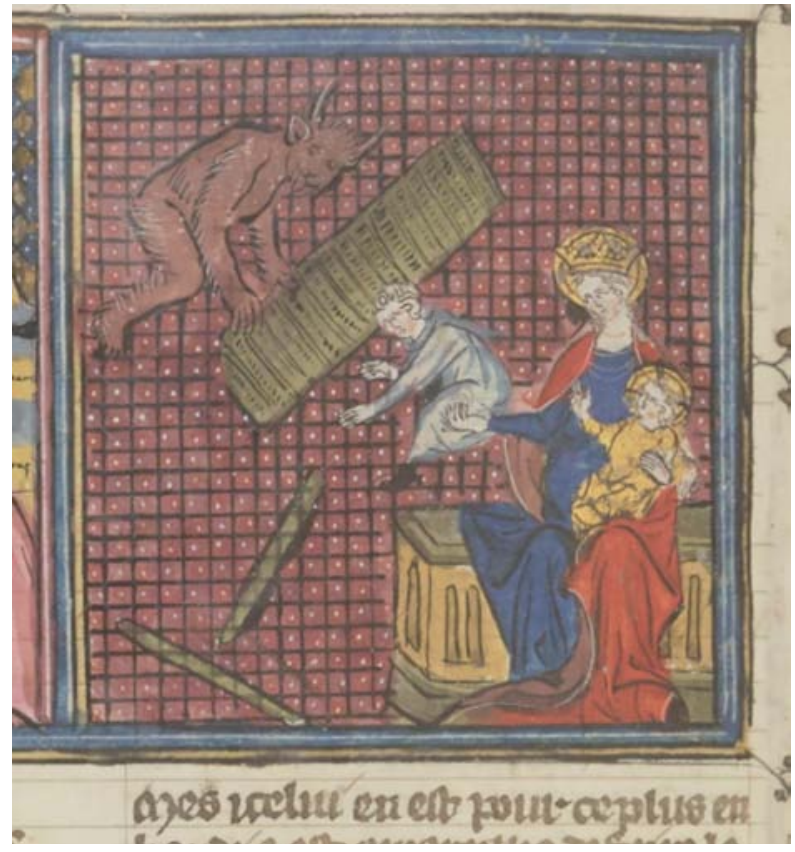

Fig. 16. El milagro del pintor. Vicente de Beauvais, Miroir Historial trad. Jean de Vignay, París, Biblioteca Nacional de Francia, MS français 316, fol. 292v (c. 1333).

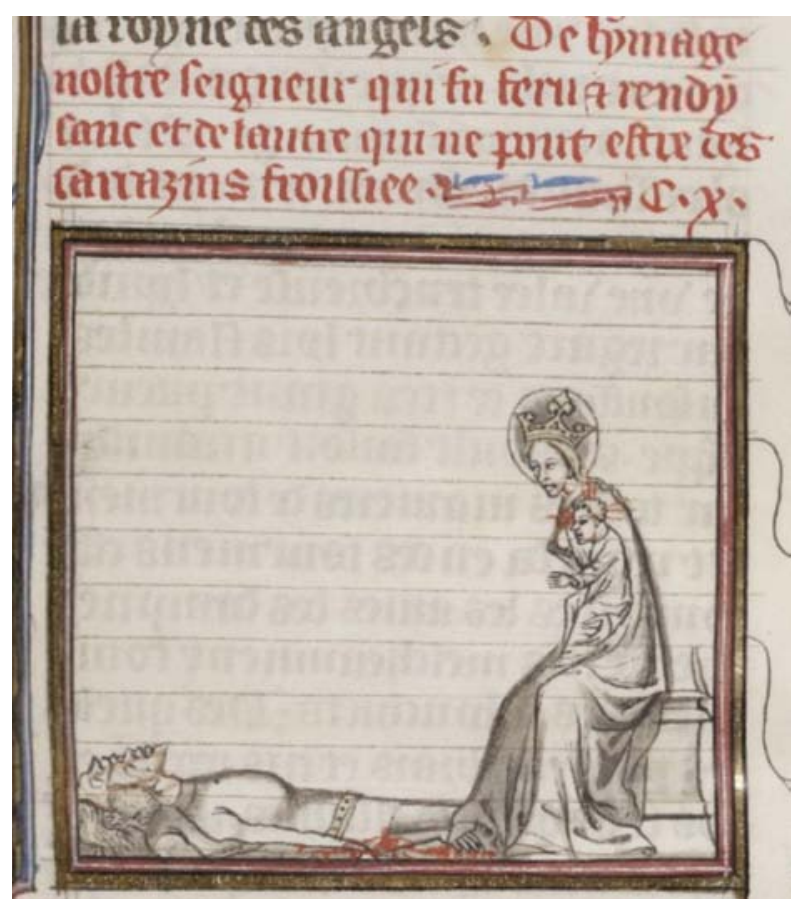

Fig. 18. La imagen lapidada. Vicente de Beauvais, Miroir Historial trad. Jean de Vignay, París, Biblioteca Nacional de Francia, MS français 312, fol. 342r (c. 1396).

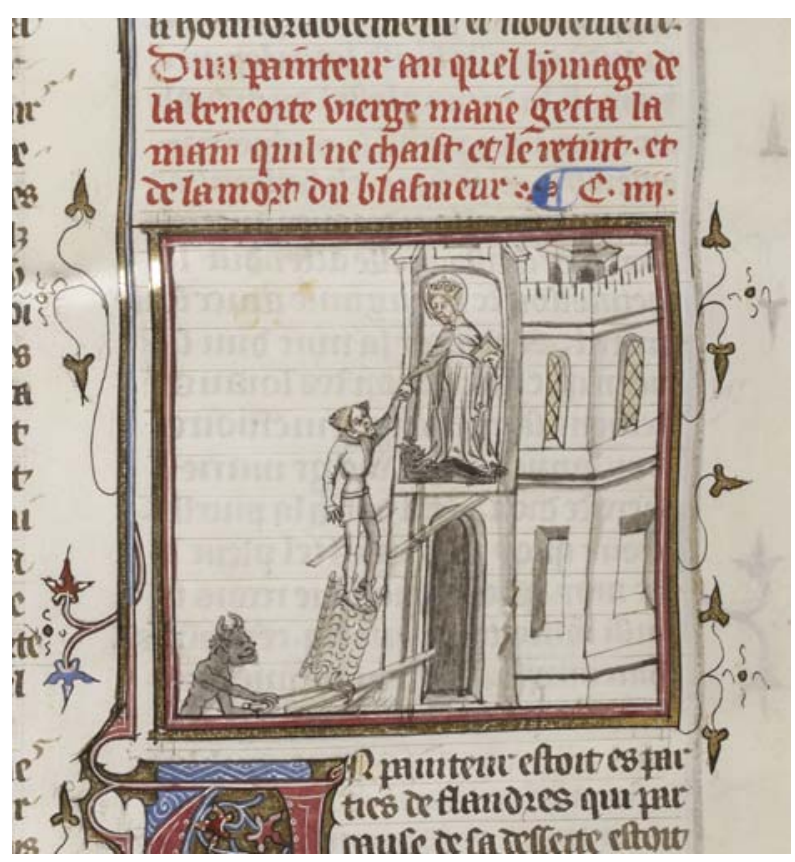

Fig. 17. El milagro del pintor. Vicente de Beauvais, Miroir Historial trad. Jean de Vignay, París, Biblioteca Nacional de Francia, MS français 312, fol. 338v (c. 1396).

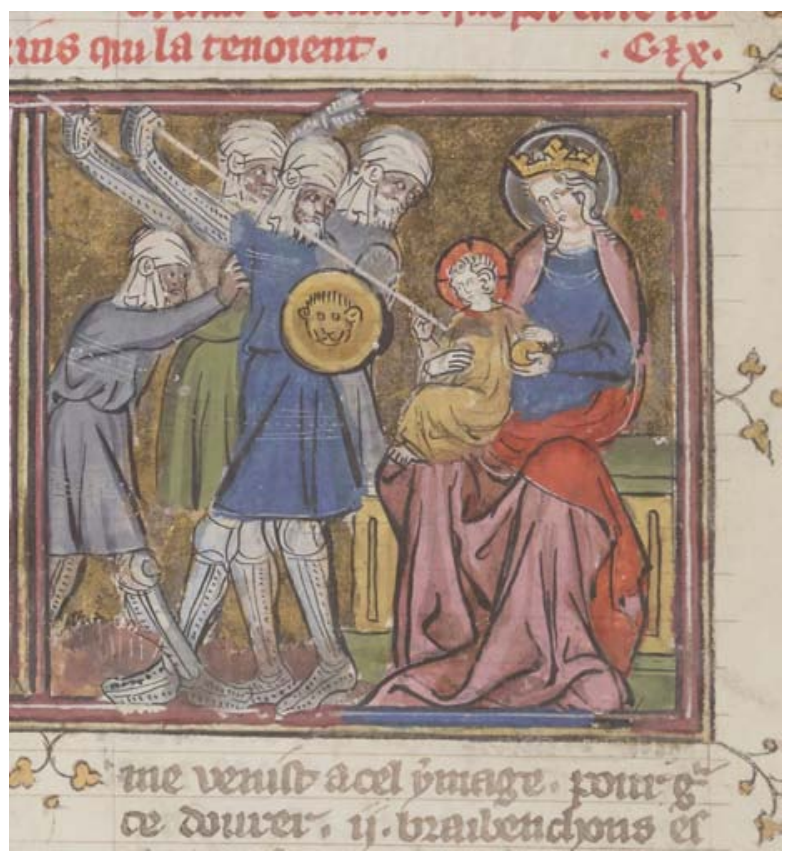

Fig. 19. La imagen profanada por un grupo de sarracenos. Vicente de Beauvais, Miroir Historial trad. Jean de Vignay, París, Biblioteca Nacional de Francia, MS français 316, fol. 297r (c. 1333). 
Por tanto, en los últimos siglos de la Edad Media la cultura visual en torno a las imágenes marianas camina hacia la dirección planteada por Michael Camille, la ruptura de la relación con su prototipo, confundiéndolas y dejando de lado su aspecto de simple representación. Una idea que incluso llega a modificar la propia descripción de los relatos. Las miniaturas en los manuscritos del Miroir Historial reflejan una evolución sustancial a este respecto, puesto que, si las comparamos con los repertorios de las colecciones ilustradas en el siglo XIII, la imagen pasa de ser una imagen pintada o esculpida a una personificación individualizada tanto en el espacio público como en el privado. La legitimación de su culto fue un factor determinante pero no el único. La percepción de que la materia podía ser modificada por acción divina y la propia naturaleza cercana de la Virgen impulsaron una visión de sus imágenes que, bajo el amparo del milagro, acaban convirtiéndose en sustitutas eficaces y reales de su modelo.

FUENSANTA MURCIA NICOLÁS es doctora con mención internacional en Historia del Arte por la Universidad de Murcia (2015). En la actualidad es investigadora postdoctoral en el Centre d’Études Supérieures de Civilisation Médiévale de Poitiers desde abril del año 2018. Con anterioridad ha disfrutado de varias ayudas y contratos predoctorales, como la beca-contrato FPU del Ministerio de Educación (2011-2015) y ha participado en tres proyectos de investigación financiados por el Ministerio de Ciencia (2010,2019) y Economía (2013). Sus investigaciones indagan en la teoría y práctica sobre las imágenes de culto en la Edad Media occidental y el patronazgo librario femenino en Francia, de las que ha publicado varios artículo indexados en ERIHplus (Codex Aquilarensis 2011 y 2012, Anales de Historia del Arte 2014) y SCOPUS (Ikon 2017), así como una monografía científica editada por la Fundación Santa María la Real del Patrimonio Histórico (2016). Recientemente ha colaborado con Jean-Marie Sansterre en su monografía Les images sacrées en Occident au Moyen Âge (Akal, 2020, en prensa), y ha sido conferenciante invitada en la International Medieval Society of Paris (2014), el Centre d'Études Supérieures de Civilisation Médiévale (2018) y en las Journées Romanes de Saint-Michel de Cuxa (2019).

Email: f.murcia.nicolas@gmail.com

Código ORCID: https://orcid.org/0000-0003-0063-3708 